NBER WORKING PAPER SERIES

\title{
HIGH-FREQUENCY CONTAGION OF CURRENCY CRISES IN ASIA
}

\author{
Takatoshi Ito \\ Yuko Hashimoto \\ Working Paper 9376 \\ http://www.nber.org/papers/w9376
NATIONAL BUREAU OF ECONOMIC RESEARCH
1050 Massachusetts Avenue
Cambridge, MA 02138 \\ December 2002
}

The authors are grateful for comments from Munehisa Kasuya (Bank of Japan), Eiji Ogawa (Hitotsubashi University), Shin-ichi Fukuda (University of Tokyo), Jing-Lung Henry Lin (Academia Sinica, Taipei and UCSD) and conference and seminar participants at The $8{ }^{\text {th }}$ International Convention of East Asian Economic Association, 2002 International Conference Asian Crisis 4, 2001 Fall Annual Meeting of Japanese Economic Association, 2001 Summer Tokei Kenkyu-kai Conference, Keio University, Institute of Economic Research at Hitotsubashi University, Institute for Monetary and Economic Studies, Bank of Japan. The views expressed herein are those of the authors and not necessarily those of the National Bureau of Economic Research.

(C) 2002 by Takatoshi Ito and Yuko Hashimoto. All rights reserved. Short sections of text, not to exceed two paragraphs, may be quoted without explicit permission provided that full credit, including (C) notice, is given to the source. 
High-Frequency Contagion of Currency Crises in Asia

Takatoshi Ito and Yuko Hashimoto

NBER Working Paper No. 9376

December 2002

JEL No. F31, G12, G15

\begin{abstract}
Using daily data during the period of Asian Currency Crises, this paper examines highfrequency contagion effects among Asian six countries. By identifying the "origin" (of exchange rate depreciation, or decline in stock prices) and the "affected" (currencies, or stock prices) in spillover relationship, Indonesia and Korea are found to be the two main origin countries, affecting exchange rates and stock prices of other countries. Evidence of high-frequency crisis spillover from Thailand to other countries was weak at best. A positive relationship between trade link indices and the contagion coefficients is found, implying that the bilateral trade linkage is an important factor for currency market participants to expect which currency should be affected within days of an original a shock in the exchange rate of a particular country.

Takatoshi Ito

Research Center for Advanced

Science and Technology

University of Tokyo, Japan

4-6-1 Komaba, Meguro-ku

Tokyo, 153-8904 Japan

and NBER

ITOINTOKYO@aol.com

Yuko Hashimoto

Faculty of School and Media Governance

Keio University

Japan

5322 Endoh, Fujisawa-city

Kanagawa, 252-8520 Japan

yhashi@sfc.keio.ac.jp
\end{abstract}




\section{Introduction}

The collapse of de facto dollar peg of Thai Baht on July 2, 1997 has had devastating financial and economic effects on most of neighboring countries in East Asia. In January 1998, when the crisis was in its worst state, the cumulative depreciation rate since end-June 1997 was about 50 percent for most of the currencies in the region. Among them, the value of the Indonesia Rupiah had become one-sixth of the pre-crisis level. The degree of Contagion of currency crises in Asia was remarkable.

A sudden and huge capital outflow was one of the key reasons for the Asian currency crisis, by causing depreciation of currencies, higher interest rates, and plummeting stock prices in many countries in 1997-98. ${ }^{1}$ The Asian currency crisis, as a capital account crisis, was preceded by the Mexican crisis, and followed by crises in Russia, Turkey, Brazil, and Argentina. However, contagion in terms of currency crises in regions other than Asia was limited, in its scope and its speed. In case of the Mexican Peso crash of 1994, several emerging stock markets in the region fell as investors "ran for cover": countries like Argentina and Brazil were expected to be next in a series of currency crises. The support program for Argentina by IMF in March 1995 turned out to be successful in managing the "tequila effect". The global financial turmoil triggered by Russia's default in 1998 increased risk premium in many emerging markets, but few countries suffered currency crises following Russia. ${ }^{2}$

What was striking in case of Asia was (1) crises in several Asian countries occurred almost contemporaneously in time, and (2) the most affected countries seemed to have shifted from one country to another. Within a few days after the Thai baht floatation in early July 1997, speculators attacked Malaysia, Philippines, and Indonesia. Hong Kong and Korea were attacked somewhat later on. The Asian Crisis differs from other crises in its depth and width of contagion.

\footnotetext{
${ }^{1}$ See for example, Corsetti, Pesenti and Roubini (1998a, b), Flood and Marion (1998), Radelet and Sachs (1998), Yoshitomi and Ohno (1999), Ito (1997), Ito (2000), to name a few.

${ }^{2}$ Short-term interest rate soared from $59 \%$ as of June 1998 to $200 \%$ as of August 1998 . Long Term Capital Management (LTCM) suffered a heavy loss due to a sharp increase in bond spread of developing countries and requested bail out package for the Federal Reserve Bank. In order to avoid further default and liquidity contraction in market, FRB cut interest rates three times during September - November 1998.
} 
In this paper we examine high-frequency contagious effects among Asian six economies (Indonesia, Korea, Malaysia, Philippines, Taiwan and Thailand) for the period of Asian Currency Crises. ${ }^{3}$ We use daily data to capture the day-to-day movements in the financial market and identify "first victim" currency (stock price), based on the methodology of the high frequency analysis in the finance theory.

We attempt to answer the following two questions: first, given a large depreciation in the first attacked country, to which extent the neighboring countries suffer? And second, which country is most likely to be affected during turbulent times?

Our paper is the first among papers in that the "origin" (of exchange rate depreciation, or decline in stock prices) and the "affected" (currencies, or stock prices) are distinguished by measuring the degree of depreciations. The "origin" is assumed to be the one that suffers the most declines in its value. More specifically, we classify daily depreciation of each country into two groups: a currency that showed the largest depreciation among six currencies as the "origin" and others as the "affected".

In consideration of the difficulty of distinguishing the origin and the affected, based on the time lag, because a currency crisis in one country simultaneously spills over to neighboring countries, we presume the simultaneous (high-frequent) contagion as the spillover effect from the most seriously attacked - and thereby the largest depreciated- country to others.

We then investigate channels through which the crisis is transmitted across countries. In examining the high frequency contagion, it is necessary to consider the markets' perception since a piece of new information may cause a sudden shift in expectations and confidence in the market. Thus, we consider several factors such as news and macroeconomic fundamentals (trade linkage) that investors would take into account for as the crisis transmission channel.

In order to see whether our classification of origin and affect reflects the reality, we check country-specific news of the date we refer to the country as origin from Bloomberg. Then, in the

\footnotetext{
${ }^{3}$ Hong Kong and Singapore are precluded from the survey because (1) Hong Kong adopted Currency board system even after the onset of crisis and therefore continued to peg its currency to the US dollar, and (2) the depreciation of Singaporean dollar was relatively small.
} 
benchmark regression, we set the origin as explanatory variable to estimate the degree of spillover from a country with the largest depreciation to others: we call this the contagion coefficient. We find evidence of high-frequency causality: a currency crisis appears to spillover to other currencies. ${ }^{4}$

The structure of the rest of the paper is as follows. In section 2, the existing literature on currency crises and contagion is reviewed. Section 3 summaries exchange rates and stock prices of the region during the crisis period. In section 4 the "origin" and the "affected" are defined. In section 5 we present empirics and in section 6 we apply time series analysis. In section 7 we study the relationship between high-frequency contagion and trade link channel. Section 8 concludes the paper.

\section{Previous Studies on Currency Crises and Contagion}

There is a growing literature on the empirical evidence on currency crises and its contagious effects. We have seen at least three important currency crises in the 1990s and many papers have been written on these crises. Collins (1992) and Otker and Pazarbasiouglu (1997) investigate the 1992-93 crises in the European Monetary System. The Tequila crisis is surveyed in Sachs, Tornell and Velasco (1996) and Ito (1997), among others. Corsetti, Pesenti and Roubini (1998a, b), Radelet and Sachs (1998), Baing and Goldfajn (1999), and Berg and Pattillo (1999) investigate the Asian crisis.

What we have learned are, in general, two main interpretations of the causes of crises. According to one view, currency crisis reflects economic conditions in countries—structural and policy distortions, and weak fundamentals. As shown in Kaminsky, Lizondo and Reihnart (1998), some macroeconomic variables show weakness during months, if not years, prior to a

\footnotetext{
${ }^{4}$ Some point out the possibility of the accumulated effect: that is, an affected country falls into a more severe crisis than the origin country in the spillover process. If we see the Asian currency crisis as the accumulated effect from the initially targeted country, then the Thai baht devaluation alone should be interpreted as the Asian Currency Crisis. In our analysis, we do not take into account the accumulated effect during the course of the Asian currency crisis. We detail the contagious phenomenon from various points of views.
} 
crisis. In these cases, it may be necessary to impose strict macroeconomic conditionality on these countries in order to avoid further crises. If one believes that a crisis happens due to weak fundamentals, crises in several countries in one region may be regarded as independent crises that happen to occur simultaneously. The simultaneity may be due to common global shocks, such as the global interest rate hike as well as sheer coincidence.

Another view focuses on sudden shifts in market expectations and confidence --- caused mainly by investors' panic and herd behavior--- regardless of macroeconomic performance. In a financial market where participants share access to much of the same information, a piece of new information (e.g., a small attack on a currency) can provide a signal that lead to a revision of expectations (an information cascade) in the market. The market's perception may be interpreted by currency traders in other markets as an eventual occurrence of a crisis in the near future. ${ }^{5}$ This effect could lead to a capital outflow from the market and could result in an attack on currency despite of sound macroeconomic fundamentals. In this case, countries that face difficulties in managing reserves and capital outflows should be rescued with financial assistance from the international community without any conditionality. ${ }^{6}$ If investors' sentiment plays a big role, contagion may be a result of a shift in investors; view on neighboring countries when one country goes into a crisis.

In addition to these literatures, there is a lot of literature on contagion in currency crises. There are at least four channels through which instability in financial markets might be transmitted across countries.

First, trade links can be a channel for contagion. This channel suggests that currency crises will spread contagiously among countries that trade disproportionately with one another. The devaluation in a country boosts up its competitiveness at least temporarily, in the presence of nominal rigidities. Then its trade partners are at a competitive disadvantage. Deterioration in

\footnotetext{
${ }^{5}$ Agenor and Aizenman (1998) investigate currency crisis based on the imperfect credit market. 6 The IMF's new precautionary facility Contingent Credit Lines (CCL), approved by the IMF Executive Board in 1999, was designed to assist countries with strong economic policies and sound financial systems that are seeking to resist contagion from disturbances in global capital markets.
} 
terms of trade will also worsen their economic performances in the mid- and long- run. Those most-adversely-affected countries are likely to be attacked next. Glick and Rose (1998) find the correlation between the spread of crisis and trade links.

Second, a channel through common creditors may explain spillovers of a crisis. The common creditor hypothesis is based on the lending institutions' tendency to ensure the immediate liquidity. When financial institutions face a default in one country, they tend to withdraw capitals not only from the country but also from other countries so that they will avoid further decline in their asset values. Kaminsky and Reinhart (2000) provide related analysis.

Third, sudden changes in assessment of emerging market countries among investors and lending agencies may cause the contagion. The Wake-up call hypothesis states that investors change the risk assessment to other countries in the wake of one crisis and become pessimistic toward investment or even rush the recovery of credit. Macroeconomic or financial similarities are often trigger re-assessment. A crisis may spread from the initial crisis country to another if the other has similar economic conditions, such as the Current Account to GDP ratio, the Foreign Reserves to short-term borrowings ratio, and so on. Sachs, Tornell and Velasco (1995) put on contagion in this light. ${ }^{7}$

It should also be noted that the concept of "contagion" varies from author to author.

For one case, we can think of a currency crisis as being contagious if it spreads from the initial crisis country to another. ${ }^{8}$ Masson (1999a) argues based on multiple equilibria model that crisis contagion can be referred as an equilibrium switch under some economic fundamental conditions. ${ }^{9}$ The alternative view is that the contagion

\footnotetext{
${ }^{7}$ Literature based on Macroeconomic fundamentals, see Collins (1992), Flood and Marion (1994), Eichengreen, Rose and Wyplosz (1994, 1996), Otker and Pazarbasioglu (1997), to name a few. Kaminsky, Lizondo and Reinhart (1998) is an excellent survey on empirical literatures. Berg and Pattillo (1999) argue the crises predictability.

${ }^{8}$ Masson (1999 b) classifies the causes of currency crisis into three: ( 1 ) common cause (monsoon effect), (2) fundamentals (spillover effect), and (3) trigger of first and hard hit country (sentiment jump). ${ }^{9}$ Flood and Marion (2000) focus currency crisis based on models of multiple equilibria. Jeanne and Masson (2000) apply the Markov Switching model. Obstfeld (1996) incorporates unemployment rate to the multiple equilibria model.
} 
effect is thought of as an increase in the probability of a speculative attack on the domestic currency. See Eichengree, Rose and Wyplosz (1996), for example, for this view.

As is well known, it is difficult to distinguish empirically between common shocks and contagion, especially in the middle of crisis. In both explanations above, the actual occurrence (or an increase in probability) of crises depends on the existence of a (not necessarily successful) speculative attack elsewhere in the world.

In this paper, we measure the contagion coefficient as the ratio of depreciation of currency (or a decline in stock prices) of one country to that of the initial crisis country. In order to see if large movements of exchange rates are caused by the common shocks that simultaneously affected several countries or a crisis and its contagion in the region, we check the news release relevant to the date of large depreciation from Bloomberg. We find that Asian exchange rate movements during the crisis period were highly sensitive to crisis-related statements, such as the financial systems, bankruptcies, and political instability of a country where the currency depreciated most.

Our objective in this paper advances these viewpoints to analyze intra-day spillover effect from the first affected country, namely the high frequency contagion. We do not judge why the original crisis happened either by bad fundamentals (first generation model) or by a self-fulfilling attack (second generation model). Instead, the size of contagious effect from "ground zero" to other countries is measured, given the incidence of the initial attack. To anticipate a result, it is found that a high-frequency contagion phenomenon can be explained by the trade linkage within Asia. See, Glick and Rose (1999) and Eichengreen, Wyploz and Rose (1996).

One of the most significant weaknesses of earlier literatures on contagion is the absence of distinguishing the origin and affected in causality relationship. In the financial market, investors are likely to respond to an attack by withdrawing capital not only from the first attacked country, but also from neighboring countries within a few days, if not hours. In this respect, using monthly or quarterly data, even weekly data, on which many previous analyses based, may limit 
analytical capability of crisis correlations among countries during a crisis period.

Our measure of contagion permits us to identify systemically important countries. Namely, whose contagion effects are significant and sizable can be found.

\section{Exchange Rate and Stock Price during the crisis period}

The daily data of the nominal exchange rate (vis-a-vis US dollar) and stock prices of Indonesia, Korea, Malaysia, Philippines, Taiwan and Thailand are used. ${ }^{10}$ The sample period begins at January 3, 1997 for the exchange rate and January 3, 1994 for stock prices and ends at July 7, 1999 for both series. Both the exchange rate and stock prices data are obtained from Datastream.

$$
\text { Figure 1-1 (exchange rate, June } 30 \text { 1997=100) }
$$

Figure 1-1 shows the exchange rates of six currencies against US dollar from June 30, 1997 to July 7, 1999. They are normalized at 100 on June 30, 1997. The behavior of exchange rates through the crisis period varied considerably across the countries. In Thailand, after an initial sharp depreciation due to the floatation of the baht on July 2 , 1997, there were a series of smaller, but still substantial depreciation over a prolonged period, culminating in 17 percent depreciations by the end of August. The pressures were eased in September in response to measures to prevent further depreciation. We can see that a large depreciation in Thai baht initially had a substantial impact on Philippines peso and Indonesia rupiah.

In contrast, Indonesia's exchange rate depreciated fairly steadily starting in July 1997. Pressure on the Indonesia rupiah was intensified in late September due to increased problems in the financial market, but complicated by the political sector. With the rupiah falling further against the U.S. dollar by early October, IMF-supported programs for Indonesia were

\footnotetext{
${ }^{10}$ Stock price indices are: Jakarta Composite Index (ID), Korea South Composite Index (KR), Composite Index (ML), Composite Index (PH), Weighted Index (TW), Bangkok Book Club (TH).
} 
announced on October 31, 1997. Then, Indonesia rupiah recovered temporarily in response to the program. ${ }^{11}$ The limited recovery in the next few weeks was reversed by large further depreciation starting in late 1997 to mid 1998.

Korea avoided substantial depreciation until October 1997, with the exchange rate remaining broadly stable in July-October 1997. However, as Korean banks began to face difficulties in rolling over their short-term foreign liabilities, the exchange rate fell precipitously during late November- end December 1997.

\section{Figure 1-2, stock prices}

Figure 1-2 plots stock price indices of 6 countries from January 3, 1994 to July 7, 1999, with January 3, 1994=100. It is obvious from this figure that the stock market paints a different picture from the exchange rate market. Stock prices of Thailand peaked in 1994. On the other hand, stock prices of Indonesia, Korea, Malaysia, and Taiwan continued to increase or had been stable until late 1996.

Stock prices of Korea, Malaysia and Philippines began to fall in December 1996. In Indonesia, stock prices even increased through mid-1997, but fell sharply in the aftermath of the Thai crisis. Stock prices of Taiwan also fell by some extent, but its level in mid 1997 still exceeded the 1994 price level. In October 1997, stock prices of Korea and Malaysia dropped significantly. ${ }^{12}$ The declines in stock prices continued until September 1998, then headed for recovery except Thailand and Malaysia.

\section{Definitions of "origin" and "affected"}

In the midst of the crises, many currencies depreciated at the same time. For instance, a large depreciation of the Thai baht seemed to have made a substantial impact on Philippines peso

11 On November 5, 1997, the IMF's Executive Board and Indonesia approved a three-year Stand-By Arrangement equivalent to $\$ 10$ billion. Additional financing commitments included $\$ 8$ billion form the World Bank and the Asian Development Bank, and pledges from interested countries amounting to some $\$ 18$ billion as a second line of defense.

${ }^{12}$ In October 1997, Hong Kong dollar was targeted of speculative attack and the Currency Board system raised interest rate that resulted in a decline in stock prices. So, several measures to shore up the stock market, including public funds injection, were taken. 
and Indonesia rupiah and then it made a feedback to the Thai baht. In order to analyze statistically the size and the direction of spillover effect, we differentiate the "ground zero (origin)" from the "affected" countries.

In order to sharpen our analysis, we use the daily data. The problem of using a low frequency data (semi-annual, quarterly, and monthly), on which many previous literature are based, is that it smoothes out a lot of shorter duration interactions between the markets. Low frequency data makes it difficult to capture small but important events in the sample period. The feedback movements explained above would be grossed over by the use of monthly or quarterly data.

We first construct an indicator that distinguishes the "origin" from others that are referred to as "affected". To sketch the idea briefly, we first show the weekly (Friday to Friday) origin. It is calculated based on the weekly change in the exchange rate. Weekly origin of a crisis is a currency that depreciated most in the week with its depreciation exceeding $4 \%$. This cut off number is ad hoc.

Table1-1 plots weekly origin of exchange rate depreciation, from July 1997 to January 1998.

\section{Table 1-1, weekly origin}

One problem using weekly change as origin is that weekly origin depends on the choice of the day of the week. Think of a currency that depreciates 3 percent from Thursday to Friday and then again 2 percent from Friday to Monday. Using the definition of 4-percent-cut-off depreciation starting on Friday does not pick this currency as origin; while, Monday-to-Monday origin does.

Now, a new way of defining origin is developed.

First, daily percentage change of the exchange rate (stock price) is written as:

$$
D R(t, j)=R(t, j)-R(t-1, j)
$$


where $R(t, j)$ is log of nominal exchange rate (country $j$ ) with respect to the US dollar at date $t$. We next compute the weighted cumulative change, $\operatorname{DRR}(t, j)$, as the weighted cumulative change with the declining weights of past DRs ${ }^{13}$ :

$$
\begin{aligned}
\operatorname{DRR}(t, j)=0.5 \mathrm{DR}(\mathrm{t}, \mathrm{j}) & +0.25 \mathrm{DR}(\mathrm{t}-1, \mathrm{j})+0.125 \mathrm{DR}(\mathrm{t}-2, \mathrm{j}) \\
& +0.0625 \mathrm{DR}(\mathrm{t}-3, \mathrm{j})+0.0625 \mathrm{DR}(\mathrm{t}-4, \mathrm{j}) .
\end{aligned}
$$

The rationale for our measurement of origin based on DRR, not on DR, is as follow. It is often observed that a large depreciation (decline in stock price) followed by a large recovery in order to correct the overshooting. For example, both currency A and B were heavily hit to depreciate 11 and 10 percent respectively. Next day, currency A showed a recovery of 8 percent, while currency B did only 2 percent. It would be appropriate to interpret that currency B was more severely targeted. DR-based-origin, however, counts A as ground zero. We are likely to misjudge the severity of crisis should we see only the daily percentage change of depreciation. Using DRR, country B will be identified as a crisis country.

Our declining weight formula is also intended to avoid lingering effects of large changes of days ago. A crisis is not judged as severe when the rate of depreciation (decline in stock price) is large, but one-time-only. If we assume the equal weights, then, a very large depreciation of 5 days ago would influence the selection of the current origin of a crisis.

Our "origin" measure, DOR, is defined as follows:

$\operatorname{DOR}(t, 0)=$ largest DRR at each $\mathrm{t}$ and also whose depreciation rate exceeds $2 \%{ }^{14}$

\footnotetext{
${ }^{13}$ The weights are arbitrarily chosen. The optimal weight (coefficient) may be computed from running VAR, but this method would not be plausible for East Asian countries since they pegged their currencies to US dollar prior to 1997.

${ }^{14}$ The threshold of $2 \%$ is arbitral.
} 
Table1-2 and Table 1-3 summarize the $\operatorname{DOR}(\mathrm{t}, 0)$ of exchange rates and stock prices, respectively.

Table 1-2; Daily origin of exchange rate, Table 1-3; daily origin of Stock price

Table 1-2 lists the origins determined by DOR for the exchange rate depreciation from July 1997 to July 1999. The table makes it possible to pin down the crisis date in each country. For instance, July 1997 for Thailand, August-September 1997 for Indonesia, October 1997- January 1998 for Korea, and after January 1998 for Indonesia. With the economy back on the growth path in most of Asian countries after April 1999, the number of plots of origin declined. Our measure of origin is consistent with academic references as to the beginning of the crisis period: number of different measures gives a starting date of July 1997 for Thailand, August 1997 for Indonesia, and November 1997 for Korea.

Table 1-3 plots the origin of stock price declines. The stock price in the region was at its peak in early 1990s and then went downward by 1997 in most of countries. Since late 1994, stock prices began to fall in Thailand and fell by almost one third. The decline continued in Thailand in early 1997. In Indonesia, stock prices increased through mid-1997, but fell dramatically in the aftermath of the Thai crisis. In Korea, the decline of stock prices was temporarily interrupted in the first half of 1997 but continued in the second half in the wake of the banking sector crisis. As the contagion of exchange rate depreciation spread in the region, the downward pressure of stock prices was further intensified in Malaysia, Korea, and Indonesia. Since July 1998, stock price decline originated mainly from Indonesia, Malaysia and Philippines. The rate of decline and the frequency of large decline have been moderated since December 1998. The tremors in the stock market occurred even before the currency crisis and lingered on long after the currency started to strengthen.

In wake of financial crisis, market sentiment tends to be more volatile in general. Investors become more sensitive to bad news announcements and events. The news works as a signal to investors. A publicly available signal provides investors common information that may induce them to behave uniformly. The so-called herd behavior may result. 
Table 2 lists news release, relevant to the timing and date of exchange rate origin in Table 1-2, collected from Bloomberg. Before the July 1997 crisis, exchange rates in most of the East Asian countries did not respond to news because of the de facto peg to the US dollar. Therefore we check if the behavior of exchange rate began to reflect the news release after the floatation.

\section{Table2, exchange rate, daily origin-News}

For early stage of crisis, news was relatively straightforward and was categorized to crisis-related statement; such as authorities' announcement on exchange rate regime, foreign reserves and IMF support package. In late 1997 and early 1998, news relevant to large movements of the exchange rates became related to the vulnerability of financial and economic systems, bankruptcies, and political instability. A case can be seen that concerns on the banking system in Korea intensified the devaluation pressure at this stage. It is also argued that exchange rate movement was highly sensitive to news related to political instability in Indonesia.

\section{Matrices of Cumulative Contagion}

In order to make the idea of high-frequency contagion more concrete, a new measure of crisis spillover is proposed, namely the contagion coefficient. This is the ratio of depreciation rate of origin to that of affected country. This contagion coefficient measures high-frequent spreading of financial crisis from the origin (first attacked country) to other affected countries.

The contagion coefficient is defined as:

$$
\mathrm{CC}(\mathrm{t}, \mathrm{i})=\operatorname{DRR}(\mathrm{t}, \mathrm{i}) / \operatorname{DOR}(\mathrm{t}, 0)
$$

where $\mathrm{i} \neq 0$. Table 3-1 reports $\mathrm{CC}(\mathrm{t}, \mathrm{i})$ for exchange rate and Table 3-2 to Table 3-4 report CC(t,i) for stock price. Sample period starts on July 11997 and ends on July $71999 .{ }^{15}$

\footnotetext{
${ }^{15}$ The sample period includes when Malaysia began to peg its currency to US dollar starting at September 1, 1998. The daily percentage change in exchange rate is close to zero and so is the DRR in Malaysia after September 1998. Therefore, Malaysia is virtually excluded from "origin" for this period. Thus, we do not need to explicitly impose structural change of Malaysia on regression models in the following section.
} 
A negative sign of CC indicates the opposite movements of exchange rate (stock price) between origin and affected countries: in the case of exchange rate, a devaluation of the origin country leads to an appreciation of affected countries. On the other hand, a positive sign of $\mathrm{CC}$ indicates that the direction of exchange rate (stock price) movements between the origin country and affected countries are the same. That is, a devaluation of origin country leads to a devaluation of affected countries: namely contagion.

"t-stat (t-statistics)" in Table 3-1-Table 3-4 is the significance for testing the null hypothesis of $\mathrm{CC}$ equals zero. ${ }^{16}$ The null hypothesis implies there exists no significant high-frequency contagion from origin to affected.

\section{Table3-1 plot of CC (exchange rate), Figure 2-1}

Table 3-1 shows CC(t,i) for the exchange rate. As shown in Table 1-2, the frequency of crisis (the origin) drastically decreases after June 1998, implying that exchange rates had become stabilized or back on a recovery track by the summer 1998. Most of crisis (large depreciation) after July 1998 were from Indonesia. Therefore, we divide the sample period into four in the case of Indonesia. Specifically, for origin of Indonesia, we calculate CC(t,i) for the two sub-sample periods, crisis period (1997/7/1-12/31, 1998/1/1-6/30) and recovery period (1998/7/1-1999/7/7), in addition to the worst-state period (1997/10/1-1997/12/31).

In the case of exchange rates, there are 87 instances that are regarded as the crisis origin in terms of our definition. Of those, 60 instances are of Indonesia, 14 instances of Korea, and 7 instances of Thailand, and 6 others.

The significance of estimated coefficients varies according to sample periods and countries. The contagion coefficients originating from Thailand and from Philippines are, in many cases, negative. Shortly after the onset of currency crisis, two hard-hit currencies, the Thai baht and Philippines peso, continued the devaluation while other currencies were not severely affected and remained their value to US dollar. Thus, the contagion coefficients from these countries to

\footnotetext{
${ }^{16}$ Calculation is as follows: Stat $=\left(\mathrm{x}^{\wedge}-\mathrm{x} 0\right) /($ square root of variance $/$ square root of NOB $)$, where $\mathrm{x}^{\wedge}$ :average; $\mathrm{x} 0:(\mathrm{Null})=0$ and $\mathrm{x} 0$ is the ratio of DOR/DRR $(\mathrm{CC})$.
} 
others are not significantly different from zero.

The sign of coefficients of affected countries, when the origin is either Indonesia or Korea, is positive and significantly different from zero. That is, the large depreciation of Indonesian and Korean currencies tended to induce simultaneous depreciation in other currencies. That is, we find evidence of significant high-frequency contagion originating from Indonesia to Malaysia, Indonesia to Thailand, Korea to Malaysia, Korea to Thailand, and Korea to Indonesia.

Our high-frequency data shows that the contagion coefficients of Indonesia as the origin are positive and significant for all but Korea over the period from July to December 1997. Also, the Korean won as an origin does no $t$ affect the Indonesian Rupiah. Contrary to the conventional wisdom that the depreciation of Indonesian Rupiah won contagiously spilled over to Korean won and vice versa, the finding provides evidence that the collapse of Indonesian rupiah did not cause the depreciation of Korean won. As shown in Table 2 (news release), exchange rate movement was highly sensitive to news related to political instability in Indonesia: the concerns on the political instability intensified the devaluation pressure. The effect of Rupiah depreciation, or political instability, affected neighboring countries, but not Korea. After June 17, 1998, the result is reversed: the contagion coefficient of Indonesia is significantly positive only in Korea and insignificantly different from zero or significantly negative in other countries.

Figure 2-1 shows the significance of exchange rate contagion coefficient graphically. As seen from the figure, depreciation of Indonesia and Korea has high-frequency contagion effects on currencies in the region, while we do not find evidence of significant spillover effect from Thailand to other countries.

Table 3-2 3-4, plot of CC (stock price), Figure 2-2, Figure 2-3

Table 3-2 - Table 3-4 presents CC(t,i) of stock prices. Table3-2 shows CC for whole sample period and Table3-3 and Table3-4 present results for pre-crisis and post-crisis periods, respectively. The instances as origin as a whole dramatically increase for post-crisis, but the situation depends on pairs of countries. Figure 2-2 and 2-3 show the significance of stock price 
contagion coefficient before and after the crisis, respectively.

For Indonesia, there are 2 instances as the origin for the pre-crisis period, and 28 instances for the post-crisis period. For Korea, 3 instances for the pre-crisis and 44 for the post-crisis; for Malaysia, 4 for the pre-crisis and 25 for the post-crisis. For these 3 countries, the number of instances regarded as origin dramatically increased after the onset of crisis.

On the other hand, for the Philippines and Thailand, the number of instances before and after the crisis does not show marked difference. For the Philippines, there are 12 instances for the pre-crisis period and 15 instances for the post-crisis period. For Thailand, 17 for the pre-crisis and 16 for the post-crisis. In contrast to other countries, Taiwan is the only country whose instances as origin surprisingly decreased from 16 for the pre-crisis period to 6 for the post-crisis period.

The contagion coefficients of ASEAN countries as the origin for the post-crisis period turn to be significantly positive, and the magnitude of contagion coefficients become larger. A case for Korea as the origin, the contagion coefficients for the pre-crisis period are negative, while they become positive and significantly different from zero for the post-crisis period.

In sum, high frequency contagion of stock prices has been intensified with some exceptions in Taiwan, after the currency crisis occurred in Thailand in July 1997.

\section{Regression Results}

\subsection{Exchange Rates}

In the previous section we find high-frequency contagion in both exchange rates and stock prices among the Asian countries. The stock price high-frequency contagion becomes intensified after the crisis.

In this section, we present some formal econometric results to show statistically to what extent the depreciation of exchange rate (decline of stock prices) of first attacked country, namely origin, affects others. 
The Dynamic OLS (DOLS) method with the following specification is used: ${ }^{17}$

$$
\begin{aligned}
\operatorname{affected}(\mathrm{t}, \mathrm{i})=\mathrm{const} & +\mathrm{a} 1 * \operatorname{origin}(\mathrm{t}, 0) \\
& +\mathrm{b} 1 * \operatorname{dorigin}(\mathrm{t}+1,0)+\mathrm{b} 2 * \operatorname{dorigin}(\mathrm{t}, 0)+\mathrm{b} 3 * \operatorname{dorigin}(\mathrm{t}-1,0)+\mathrm{e},
\end{aligned}
$$

where $\mathrm{i} \neq 0$. Here, affect $(\mathrm{t}, \mathrm{i})$ is DRR and origin $(t, 0)$ is DOR defined in section 4 above, and $\operatorname{dorigin}(\mathrm{t}, 0)=\operatorname{DOR}(\mathrm{t}, 0)-\mathrm{DOR}(\mathrm{t}-1,0)$.

The Dynamic OLS method provides efficient estimator if the regressor is cointegrated or endogenous. By including the current change as well as the past and future changes of the regressor in the regression, we are able to maintain the strict exogeneity of the regressor, the origin (DOR). The order of leads and lags of changes of regressor, dorigin, is arbitrary: we set the order of both leads and lags being equal to 1 in the analysis below. Standard errors for a point estimate of a1 is recalculated based on the DOLS residuals and then adjusted to the sample period of recalculated the augmented cointegrating regression. ${ }^{18}$

For purposes of comparison, 2 types of estimation are conducted. (1) The regressor, origin $(t, \mathrm{j})$, includes all instances of being the "origin". That is, we do not distinguish the first crisis "country". We call this regressor "pooled origin". And (2) country specific origin(t,j). That is, a regression is conducted on origin according to the country. We call this "country-specific origin".

The expected sign of a point estimate of a1 is positive if there exists high-frequency contagion. Estimation results are summarized in Table 4-1.

\section{Table4-1 DOLS exchange rate}

Table 4-1 shows the estimation results for exchange rate for the period from July 11997 to July 7 1999. The first row of the table shows the regression results estimated with the pooled

\footnotetext{
${ }^{17}$ We do not include the interest rate differentials in the estimation. For the very short period of time, especially in the phase of crisis, investors do not take account of interest rate parity, but only nominal price (exchange rate, stock price). Thus, interest rate differentials are expected to be insignificant.

${ }^{18}$ See Hayashi (2000) for details.
} 
origin. The second and the third rows of the table show the estimation results with country-specific origins, Indonesia and Korea, respectively. ${ }^{19}$

Estimation results show that estimated coefficients a1 in Korea, Malaysia, Philippines and Thailand with the pooled origin are positive and significantly different from zero. The sign of estimated coefficient is, however, negative in Indonesia. The result for Indonesia can be interpreted as that the Indonesian rupiah behaved differently from others, namely no contagion in general. For example, most of the currencies in East Asia are back on recovery track around April 1998, while Indonesia rupiah continued to decline.

Estimated coefficients in Korea, Malaysia, Philippines and Thailand are significantly different from zero and the point estimates range from 0.12 to 0.19 . In contrast, the estimated coefficient is not significant in Taiwan: that is, Taiwan did not suffer the high-frequency contagion of crisis from the first-hit country. This finding is consistent with the fact that Taiwan is one of the least hit countries in 1997.

Next, estimation results on country-specific origin are examined. A case of Indonesia as origin, contagion coefficients in Malaysia, Philippines, Taiwan and Thailand are positive and significantly different from zero. In contrast, contagion coefficient in Korea is significantly negative. Indonesia rupiah severely depreciated following the Korea won in early 1998. The movement of Korean won was opposite to that of Indonesia: when Indonesia was hard hit, Korean won was on the recovery track. Therefore, the coefficient of Korea on rupiah is likely to be negative.

There seems a significant high frequency contagion in Indonesia and Malaysia in case of Korea as the origin. The estimated coefficient in Indonesia is 0.68 and significantly different from zero. The estimated coefficient in Philippines is 0.24 but insignificant, and in Thailand, significantly negative.

Two important findings emerge from the estimation results. First, there exists

19 DOLS regressions include leads and lags in both OLS and residual regressions and therefore, reduce degree of freedom. Thus, Thai origin is precluded from the regression. 
high-frequency contagion among East Asian countries. Our contagion coefficients are positive and statistically significant in most country pairs of the origin and the affected. Second, contagion effects originating from Indonesia and from Korea are significant in many countries. ${ }^{20}$

\subsection{Stock Prices}

Table 5-1 to Table 5-7 presents the estimation results for stock prices. We run regressions for three sample periods: whole sample period (January 1994-July 1999), pre-crisis (January 1994-June 1997), and post-crisis period (July 1997-July 1999). Due to the degree of freedom problem, regressions for the pre-crisis period for Indonesia, Korea and Malaysia as the origin are excluded. The regression estimates on Taiwan as the origin is not shown for the post-crisis period for the same reason.

\section{Table5-1 Table5-7 Stock Price DOLS}

Regression results of contagion coefficients estimated on pooled origin are shown in Table 5-1. Contagion effects are significant with positive coefficients in all countries for the whole sample period. The estimated coefficient is significantly negative in Korea for both pre- and post- crisis periods. However, the magnitude of coefficient becomes smaller for post crisis period. In contrast to the results that showed the intensified contagious effects for post crisis period in most countries, the magnitude of estimated coefficient in Taiwan declined sharply after the crisis. Taiwan was less influenced from high-frequency stock price contagion after the crisis.

Table 5-2 to 5-7 presents regression results estimated with the country-specific origin.

Table5-2 shows the results with the Indonesia origin. The estimated coefficients are significantly positive in both Malaysia and the Philippines.

Table5-3 is the case of Korea as the origin. All estimated coefficients, except Thailand, are significantly negative. The magnitude of estimated coefficients for the post-crisis period becomes larger (in negative) in Indonesia and Malaysia. These are consistent with the fact that

\footnotetext{
${ }^{20}$ Baig and Goldfajin (1999), for instance, use VAR to analyze impulse response among Indonesia, Korea, Malaysia, Philippines and Thailand and conclude that the impulse shock of Indonesia has significant effect on other countries. Our findings are consistent with these results.
} 
Korean stock price index declined sharply in late 1997 while stock prices in other countries remained stable.

Table5-4 reports the estimation results on Malaysia as the origin. Most of the estimates are significantly negative, but positive and significant only in Thailand.

The results of Philippines as the origin are summarized in Table 5-5. The estimated coefficients in Indonesia, Korea and Malaysia are significantly positive for both pre- and postcrisis periods. The sign of coefficients turn to be positive (but insignificant) in Thailand for the post-crisis period.

Table5-6 presents the results of Taiwan as the origin. The coefficients are all significant.

The estimation results of Thailand as the origin are shown in Table 5-7. The sign of coefficients turn to be positive (insignificant) in Indonesia and negative in Taiwan (significant) and in Malaysia (insignificant), after the crisis.

In sum, the regression results estimated on the pooled origin and on the country-specific origin do not show marked differences. The sign and significance of estimated coefficients vary from country to country depending on origin by individual countries. The estimation results with the pooled origin, however, clearly show the existence of high-frequency contagion in the stock market, especially after the crisis. This finding is consistent with a view that the change in the exchange rate regimes among the Asian countries influenced the relationship between capital markets performances, and investors started to treat the region as a whole. ${ }^{21}$

\section{Contagion and Trade Link Channel}

In this section we explore for possible channels of high-frequency contagion. Why crises spread and why they tend to be regional are, as briefly mentioned in Section 2, explained in the literature by macroeconomic similarities, the existence of common creditor, and a trade linkage.

In financial market, investors pull their capital out of countries in the same region of the

\footnotetext{
${ }^{21}$ Malliaropulos (1998), for example, reports negative relationship between the return of stock prices and the change in exchange rates.
} 
first-hit country. Investors' perception of which countries will be affected next depends on several factors including macroeconomic fundamentals and financial vulnerability. From the perspective of most empirical crisis models, however, it is hard to understand why crises tend to spread in the same region, at least at an early stage of crisis. As shown in Glick and Rose (1999), performances of macroeconomic fundamentals are not necessarily similar among crises countries.

Another transmission channel, the Common Creditor hypothesis, emphasize the role of bank lending. Lenders tend to withdraw capital not only from the first-hit country but also from others in order to avoid further losses. Figure 3-1 reports the bank liabilities in Asian six countries at the end of June $1997 .{ }^{22}$ The figure reveals that the Asian countries, most notably Indonesia, Korea and Thailand, relied on international bank credit. The common creditor hypothesis can be examined whether capital withdrawal by financial institutions, whose loan ratio to these countries are as high as that in the first-hit country, will induce depreciation. The common creditor index is calculated as

$$
\operatorname{CCI}(\mathrm{i}, 0, \mathrm{k}) \equiv \mathrm{L}_{\mathrm{i} 0} * \mathrm{~L}_{\mathrm{ik}}
$$

The loan ratio, $\mathrm{L}_{\mathrm{i} 0}\left(\mathrm{~L}_{\mathrm{ik}}\right)$, is the bank lending from country i (Japan, US, Europe) to country 0 (or k) (Asia, and $0 \neq \mathrm{k}$ ) divided by the total loan lending to the world from country i. For example, $\mathrm{L}_{\mathrm{i} 0}$ is the ratio of Japan's lending to Thailand (i=Japan and $0=$ Thailand) to Japan's total lending to the world. The loan ratio $\mathrm{L}_{\mathrm{ik}}$ is the ratio of Japan's lending to Malaysia. ( $\mathrm{i}=\mathrm{Japan}$ and $\mathrm{k}=$ Malaysia). The common creditor hypothesis states that the higher the loan ratio to the origin and other countries, the larger the withdrawal of capital from other countries. According to the hypothesis, a positive relationship between the common creditor index, $\mathrm{CCI}(\mathrm{i}, 0, \mathrm{k})$ and contagion coefficient $\mathrm{CC}(\mathrm{i}, \mathrm{k})$.

Figure 3-2 plots the contagion coefficients (CC) and the Common creditor index (CCI). The $\mathrm{CC}$ is measured on the vertical axis and the CCI is measured on the horizontal axis. The devaluation spillover from Thailand to Indonesia, from Korea to Thailand and to Indonesia, and,

\footnotetext{
${ }^{22}$ Bank for International Settlement (BIS), Consolidated International Claims of Reporting Banks on Individual Countries, by Nationality of Reporting Banks, BIS Quarterly Review, June 2002.
} 
from Indonesia to Thailand, seems to be supported by the existence of common creditors. For other pairs, however, it is difficult to find a strong relationship between common creditor index and contagion. The correlation coefficient, in total, is -0.14 . Therefore, it is difficult to interpret the results as a supportive evidence for the Common Creditor hypothesis.

\section{Figure 3-1, 3-2}

Depreciation of the first-hit country gains price competitiveness at least in the short run. Then, countries that have trading relationship with this country lose competitiveness. They are therefore more likely to allow depreciation to maintain competitiveness.

In practice, it takes some time until current trade balance deterioration will be reflected in GDP and other economic data so that depreciation is justified by fundamentals. However, investors predict the future depreciations of trading partners at the onset of a currency crisis in one country. Investors are likely to sell currencies of trading partners in anticipation of depreciation in the near future, so that depreciation happens even before the actual trading channel runs its course. Hence, theory predicts a slow process, but expectation moves events faster. That is, investors based on expectation of deterioration of trading balances of the neighboring economies in the future sells the currency immediately, resulting in high frequency contagion. This is the trade link channel through which the devaluation (or depreciation) of the first-hit currency contemporaneously spills over to other currencies in the region.

For many Asian countries, a large portion of their goods is exported to the United States, Japan, EU, and Intra Asia. ${ }^{23}$ It is tempting to believe that some direct and indirect trade linkages due to bilateral and third-market competition were instrumental in repeated rounds of competitive devaluation. There is a large volume of studies on contagion and trade link (Eichengreen and Rose (1999), Glick and Rose (1999), Forbes (2000), Kaminsky and Reinhart (2000) to name a few), and they support the evidence of relationship between the contagion and trade links.

In the following, we investigate evidence of the relationship between the high-frequency

\footnotetext{
${ }^{23}$ Export share within Asia varies between countries and ranges from $25 \%$ to $45 \%$.
} 
contagion and trade link channel using three measures; competitive effect, income effect, and cheap import effect.

\subsection{Competitive Effect}

There are three different types of explanations why contagion spreads via the trade channel in geographic proximity. The first explanation relies on the competitive effect analyzed by Gerlach and Smets (1995), and Corsetti, Pesenti, Roubini and Tille (2000). Devaluation of a first-hit country makes export prices of its trading competitors relatively more expensive. Then, market participants may expect declining trade balance in competitors due to weakened price competitiveness, and are likely to withdraw capital out of these countries.

For analysis, we provide two indices, export share and Direct Trade Linkage Index (DTLI).

\section{Table 6}

Table 6 presents the export share in intra-Asia trade for each of 5 countries (Indonesia, Korea, Malaysia, Philippines and Thailand) for $1996-1999 .{ }^{24}$ The export share of country $m$ is the ratio of export from country $m$ to country $n$ divided by the total export of country $m$. The relationship between contagion coefficient (CC) and the export share is expected to be positive. If the export share of the origin to affected countries is large, the price competitiveness of the origin affects those countries adversely. As a result, affected countries are more likely to suffer the crisis contagion from the first-hit country.

In order to look at the competitive effect more carefully, we employ another index, Direct Trade Linkage Index (DTLI), similar to that used in Glick and Rose (1999). ${ }^{25}$

$$
\operatorname{DTLI}_{0 \mathrm{i}}=1-\left(\mathrm{x}_{\mathrm{i} 0}-\mathrm{x}_{0 \mathrm{i}}\right) /\left(\mathrm{x}_{\mathrm{i} 0}+\mathrm{x}_{0 \mathrm{i}}\right)
$$

\footnotetext{
${ }^{24}$ IMF, Direction of Trade (2000).

${ }^{25}$ Although this index is similar to that in Glick and Rose (1999), the calculation is different from theirs. They focus on the absolute difference of export share between countries 0 and i, while our calculation incorporates the difference of export and import size, and direction of trade between the two countries.
} 
Here, $\mathrm{x}_{\mathrm{mn}}$ denotes bilateral exports from country $m$ to $n$. Subscript $o$ and $i$ indicate home country and its direction of trade, respectively. Thus, $\mathrm{x}_{0 \mathrm{i}}$ measures exports from home country to other country $i$, while $\mathrm{x}_{\mathrm{i} 0}$ can be interpreted as imports of home country from other country. Then, $\left(\mathrm{x}_{\mathrm{i} 0}-\mathrm{x}_{0 \mathrm{i}}\right)$ denotes the net import of home country from country $i$, and $\left(\mathrm{x}_{\mathrm{i} 0}+\mathrm{x}_{0 \mathrm{i}}\right)$ denotes the aggregate trade of home country.

The index DTLI ${ }_{0 \mathrm{i}}$ is higher than 1 if exports from country $o$ to country $i$ is greater than imports of $o$ from $i$. The index lies between 0 and 1 if imports exceed exports. The index is close to 1 if the bilateral trade between countries $o$ and $i$ are almost equal.

For example, when the bilateral trade balance from countries $o$ to $i$ is positive, then the depreciation (or devaluation) of country $o$ accelerates the export of country $o$ and, in contrast, depresses the export of country $i$ to country $o$. Then, country $i$ may suffer the disadvantage of price competition. Thus, contagion coefficient $(\mathrm{CC})$ is expected to be positively related to DTLI ${ }_{0 \mathrm{i}}$ for $\mathrm{DTLI}_{0 \mathrm{i}}>1$. On the other hand, when exports from country $i$ to country $o$ exceeds imports of country $i$ from country $o$, for DTLI ${ }_{0 \mathrm{i}}<1$, it is assumed that the price disadvantage of country $i$ resulting from the depreciation of country $o$ is less severe. So, CC may be small and/or negative. Therefore, the positive correlation coefficient between DTLI and CC is expected as a whole. The expected relationship between DTLI and CC is summarized below.

\begin{tabular}{|l||c|c|c|c|}
\hline & country 0 (origin) & country $i$ & country $i:$ price \\
competitiveness & CC \\
\hline \hline DTLI $_{0 \mathrm{i}}>1$ & export surplus & excess of import & great loss & positive \\
\hline DTLI $_{0 \mathrm{i}} \approx 1$ & balance & balance & small loss-no change & positive \\
\hline $\mathrm{DTLI}_{0 \mathrm{i}}<1$ & excess of import & export surplus & no change & small or negative \\
\hline
\end{tabular}

\section{Table 7 Figure 3-3, Figure 3-4}

Table 7 summarizes DTLI $\mathrm{D}_{0 \mathrm{i}}$. Figure 3-3 plots the contagion coefficients (CC) and the export share, and figure 3-4 plots the CC and DTLI ${ }_{0 \mathrm{i}}$. The CCs are measured on the vertical axis in both 
figures. The export share and DTLI are measured on the horizontal axis in figure 3-3 and figure $3-4$, respectively.

As shown in figure 3-3 and figure 3-4, there exists a positive relationship between CC and export share, and between CC and DTLI. The correlation coefficient of each figure is 0.329 and 0.258 , respectively.

\section{$\underline{7.2 \text { Income Effect }}$}

The second measure to relate the trade links to crisis contagion is the income effect. ${ }^{26}$ Imports of crisis country decline due to the downturn of economic activities and therefore the income level decreases. Then, its trading partners also suffer negative macroeconomic effects because of reduction in exports to the first-hit country. Countries with large export share to the first-hit country suffer from a negative income effect of the crisis country and, therefore, are likely to experience depreciation as well.

\section{Table8 Figure 3-5}

Table8 reports the income effect index. The index is represented by the export (from "affected" to "origin") to GDP ratio, export ${ }_{i 0} / \mathrm{GDP}_{\mathrm{i}}$, where $\mathrm{i}$ and o denote the affected country and the origin country, respectively. Figure 3-5 plots the index on the horizontal axis and the Contagion Coefficient on the vertical axis. There is a positive relationship between the income effect and the contagion. This correlation coefficient is 0.357 . This result implies that countries with large export share to origin country are likely to suffer currency crisis.

\subsection{Cheaper Import Effect (bilateral trade effect, supply effect)}

The third measure of trade channel is the Cheaper Import Effect (also called either bilateral trade effect or supply effect). Depreciation of the first-hit currency drives export prices down, which is equivalent to the decline in import price in its trading partners. With nominal income and other conditions held constant in a trading partner country, a decline in its import price raises

\footnotetext{
${ }^{26}$ See for example, Forbes (2000).
} 
disposable income and, therefore, improves welfare of the country. It is also expected that the terms of trade in trade partner countries improve because the import price from the origin country decreases while the export price of these countries remains constant for the short-run.

In this case, in contrast to other two trade channel effects above, depreciation of the first-hit country may have positive effect on its trading partners. As shown in Corsetti, Pesenti, Roubini and Tille (2000) and Forbes (2000), speculative pressures may not be transmitted to trading partners through the trading channel if the import price effect in trading partner countries dominates over the two previous measures.

\section{Table9 Figure 3-6}

Table 9 presents the Cheaper Import Effect. The index is calculated as the import from the origin country divided by GDP. The larger the index, the larger the import from the origin country. The contagion coefficient (CC) and the index are expected to be negatively correlated because the large devaluation in the origin country may improve its trading partners' welfare in terms of the decline of import price, and therefore trading partners are less likely to suffer crisis.

Figure 3-6 plots the $\mathrm{CC}$ and the index. It is obvious from the figure that the index has positively related to $\mathrm{CC}$. The correlation coefficient is 0.384 . This result means that the cheaper import effect does not work as to improve welfare of affected countries. Rather, the negative effect of depreciation in the origin country, especially the effect from weakened price competition, has been dominant across international trade.

All of the tests above have a consistent account. The correlation coefficients between trade link index and contagion coefficient are summarized in Table 10. As seen in this table, various measures support our high-frequency contagion and trade link channel.

\section{Table 10}

\section{Concluding remarks}

Using the daily data for the period of Asian Currency Crises, this paper examines high-frequency contagion among Asian six countries. 
By distinguishing the origin and affected countries in the causality relationship, we find evidence of statistically significant high-frequency contagion among Asian countries in both the exchange rate and the stock prices. The depreciation of Indonesia and of Korea has been found to have a significant high-frequency contagion effect on other currencies. We also find that the spillover effect in stock markets has been intensified after the crisis in most of the Asian countries.

Surprisingly, our high-frequency spillover effect is tied to the international trade channel. There is a positive relationship between the trade link indices and our contagion index. This implies that the bilateral trade linkage is an important variable in transmitting financial pressures across international borders.

\section{References}

(1) Agenor, Pierre-Richard and Joshua Aizenman (1998) "Contagion and Volatility with Imperfect Credit Markets,” IMF Staff Papers Vol. 45, No.2, 207-235.

(2) Baig, Taimur and Ilan Goldfajn (1999) "Financila Market Contagion in the Asian Crisis," IMF Staff Papers Vol. 46, No.2, 167-195.

(3) Berg, Andrew and Catherine Pattillo (1999) "Are Currency Crises Predictable? A test," IMF Staff Papers Vol.46, No.2, 107-138.

(4) Collins, Susan (1992) "The Expected timing of EMS realignments: 1979-83," NBER Working Paper No. 4068.

(5) Corsetti, Giancarlo, Paolo Pesenti, and Nouriel Roubini (1998a) "What Caused the Asian Currency and Financial Crisis? Part I: A Macroeconomic Overview,” NBER Working Paper No. 6833.

(6) Corsetti, Giancarlo, Paolo Pesenti, and Nouriel Roubini (1998b) "What Caused the Asian Currency and Financial Crisis? Part II: The Policy Debate," NBER Working Paper No. 6834.

(7) Corsetti Giancarlo, Paolo Pesenti, Nouriel Roubini and Gerdric Tille (2000) "Competitive Devaluations: Toward a Welfare-Based Approach," Journal of International Economics 51, 217-241.

(8) Eichengreen, Barry, Andrew Rose and Charles Wyplosz (1994) "Speculative Attacks on pegged exchange rates: an empirical exploration with special reference to the European monetary system," NBER Working Paper No. 4898.

(9) Eichengreen, Barry, Andrew Rose and Charles Wyplosz (1996) "Contagious Currency Crises: First Tests," Scandinavian Journal of Economics 98(4), 463-484.

(10) Flood, Robert and Nancy Marion (1994) "The size and timing of devaluations in 
capital-controlled developing economies," NBER Working Paper No. 4957.

(11) Flood, Robert and Nancy Marion (1998) "Perspectives on the Recent Currency Crisis literature," NBER Working Paper No. 6738.

(12) Flood, Robert and Nancy Marion (2000) "Self-Fulfilling risk predictions: an application to speculative attacks," Journal of International Economics 50, 245-268.

(13) Forbes, Kristin (2000) "The Asian Flu and Russian Virus: Firm-Level Evidence on How Crises are Transmitted Internationally,” NBER Working Paper No. 7807.

(14) Gerlach, Stefan and Frank Smets (1995) "Contagious Speculative Attacks," European Journal of Political Economy 11, 45-63.

(15) Glick, Reuven and Andrew Rose (1999) "Contagion and trade Why are currency crises regional?," Journal of International Money and Finance 18, 603-617.

(16) Hayashi, Fumio (2000) Econometrics, Princeton University Press.

(17)Ito, Takatoshi, 1997, Capital flow and Emergin market, Lessons from Mxico crisis (Sihon ido to sinkou sijou- Mexico crisis no kyoukun), Keizai kenkyu 48(4), 289-305, in Japanese.

(18) Ito, Takatoshi (2000) "Capital Flows to East Asia," in Sebastian Edwards (eds.), Capital Flows and the Emerging Economics: Theory, Evidence, and Controversies, University of Chicago Press.

(19) Kaminsky, Graciela, Saul Lizondo and Carmen M. Reinhart (1998) "Leading Indicators of Currency Crises," IMF Staff Papers Vol.45, No.1, 1-48.

(20) Kaminsky, Graciela, and Carmen M. Reinhart (2000) "On crises, contagion, and confusion," Journal of International Economics Vol. 51, No. 1, 145-168.

(21) Masson, Paul (1999a) "Contagion: macroeconomic models with multiple equilibria," Journal of International Money and Finance 18, 587-602.

(22) Masson, Paul (1999b) "Contagion: monsoonal effects, spillovers and jumps between multiple equilibria," in Agenor, P.R., M. Miller, D.Vines and A. Weber (eds.), The Asian Financial Crisis: Causes, Contagion and Consequences, Cambridge University Press.

(23) Obstfeld, Maurice (1996) "Models of Currency crises with self-fulfilling features," European Economic Review 40, 1037-1047.

(24) Otker, Inci and Ceyla Pazarbasioglu, 1997, Speculative attacks and macroeconomic fundamentals: evidence from some European Currencies, European Economic Review 4, 847-860.

(25) Radelet, Steven, and Jeffrey Sachs (1998) "The Onset of the East Asian Financial Crisis," NBER Working Paper No. 6680.

(26) Sachs, Jefrrey, Aaron Tornell and Andres Velasco (1996) "Financial Crises in Emerging Markets: The Lessons from 1995," NBER Working Paper, No. 5576.

(27) Yoshitomi, Masaru and Kenichi Ohno (1999) "Capital-Account Crisis and Credit Contraction: The New Nature of Crisis Requires New Policy Responses," ADBI Working Paper No.2. 


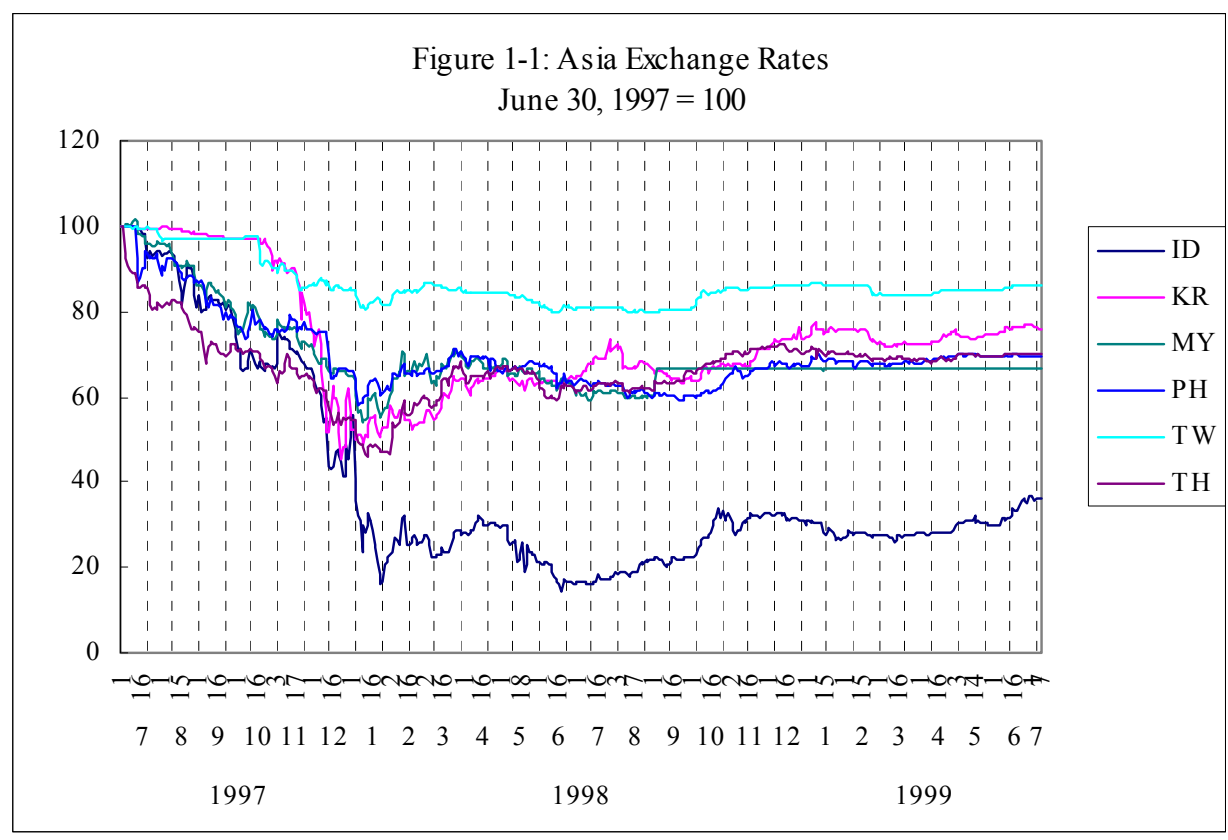




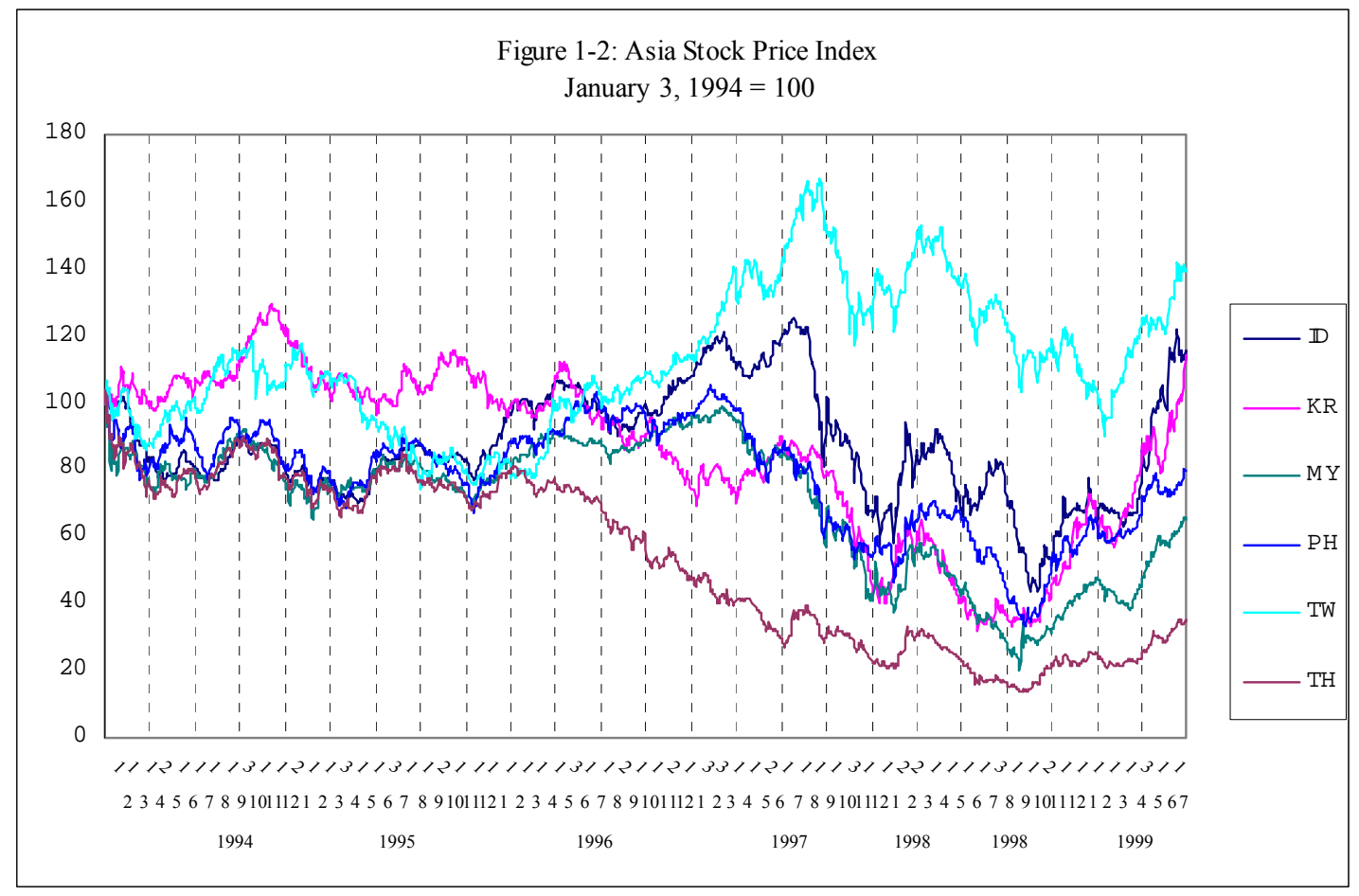


Figure 2-1

Exchange Rate Contagion Coefficient
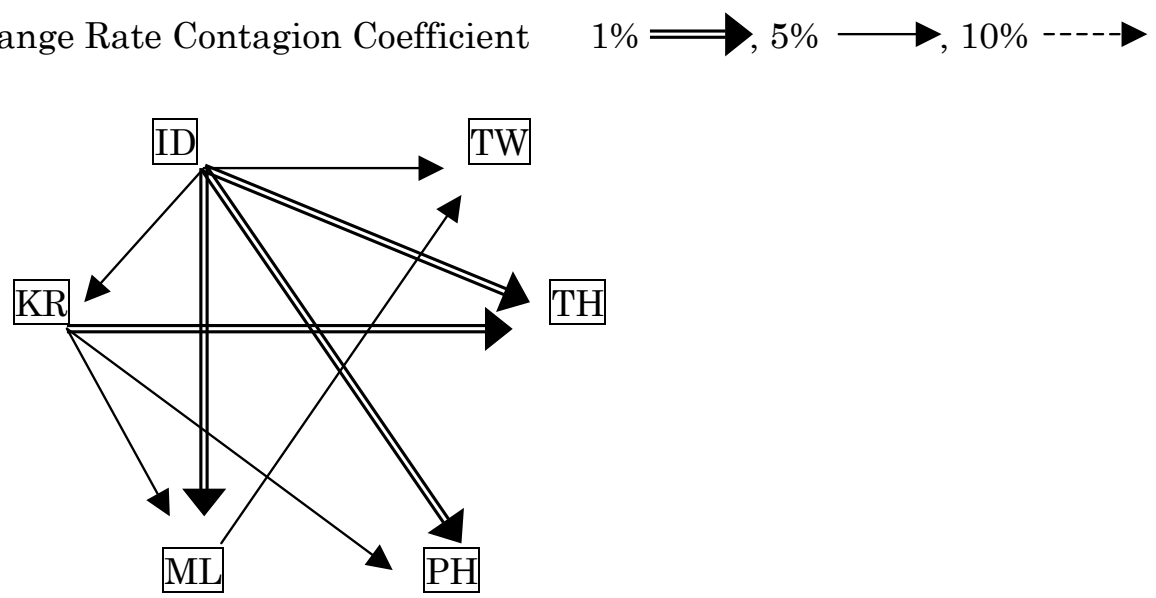

Figure 2-2

Stock Price Contagion Coefficient (before Crisis) $1 \% \longrightarrow 5 \% \longrightarrow, 10 \%----\rightarrow$

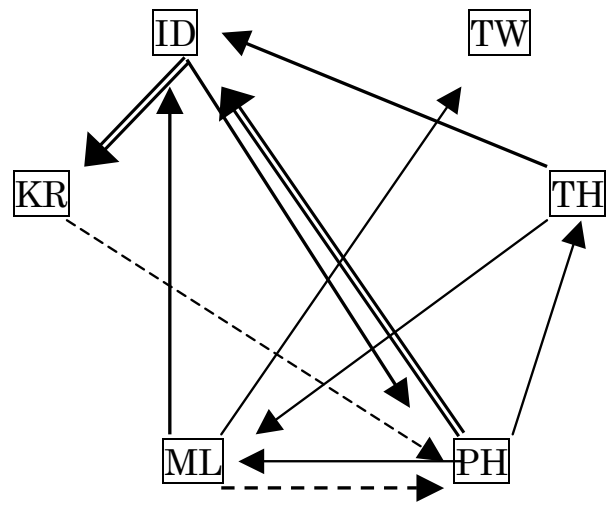

Figure 2-3

Stock Price Contagion Coefficient (after Crisis) $1 \% \longrightarrow, 5 \% \longrightarrow, 10 \%----\rightarrow$

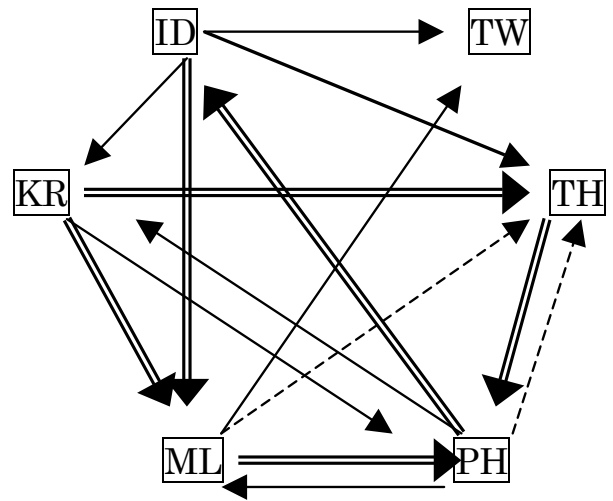




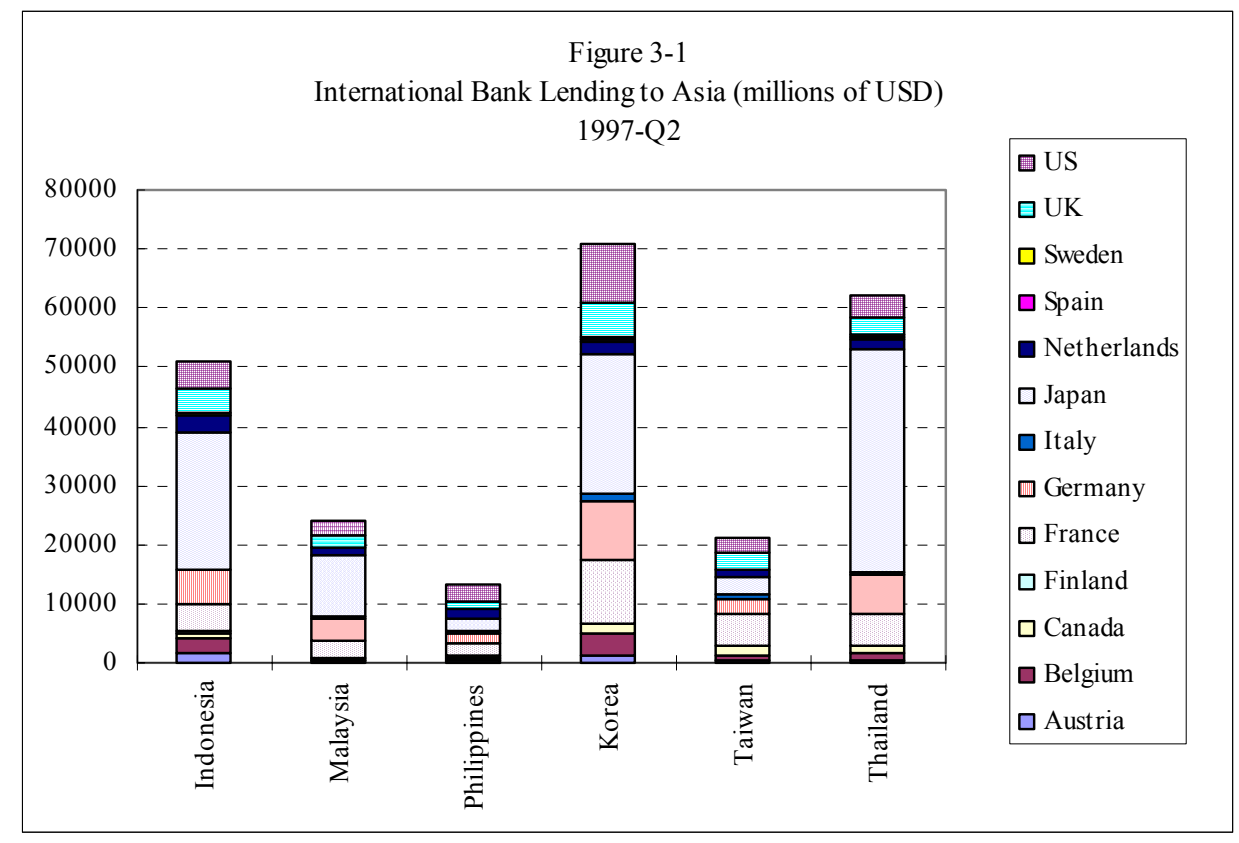




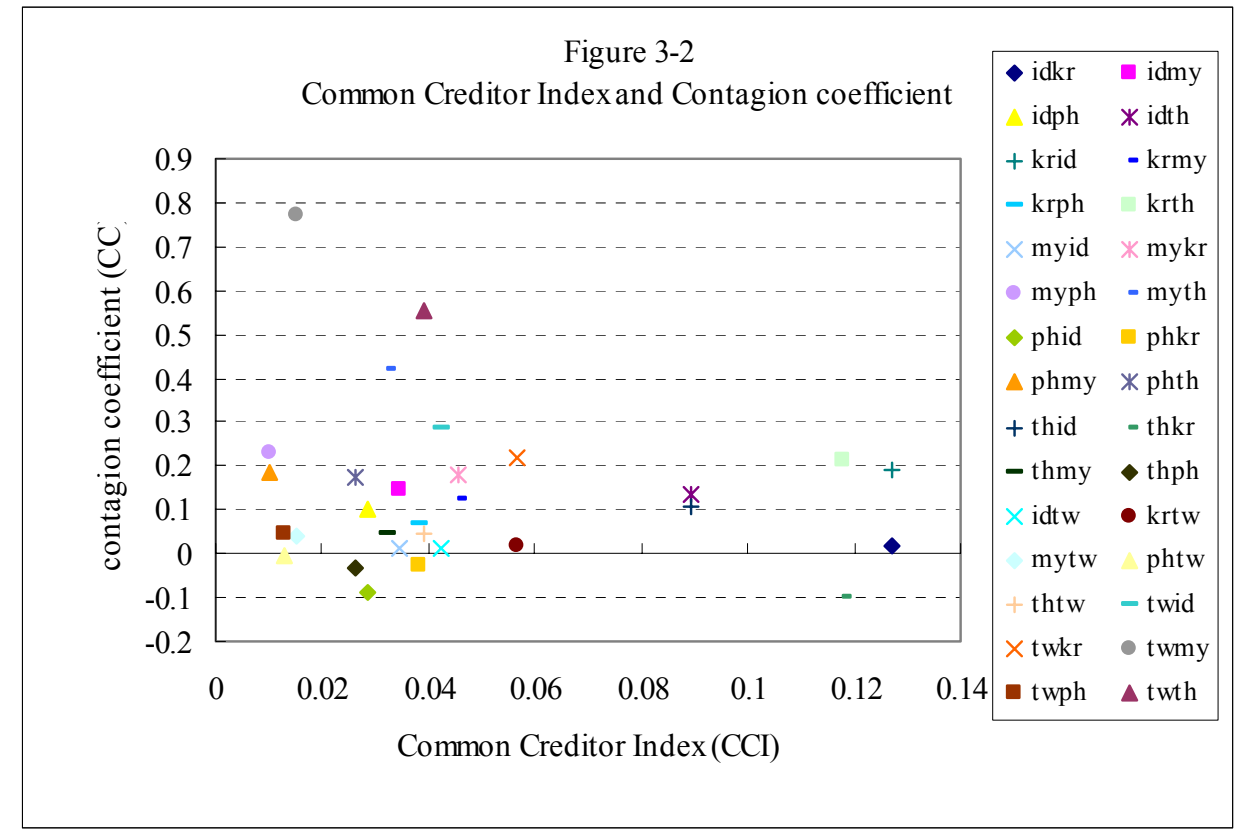




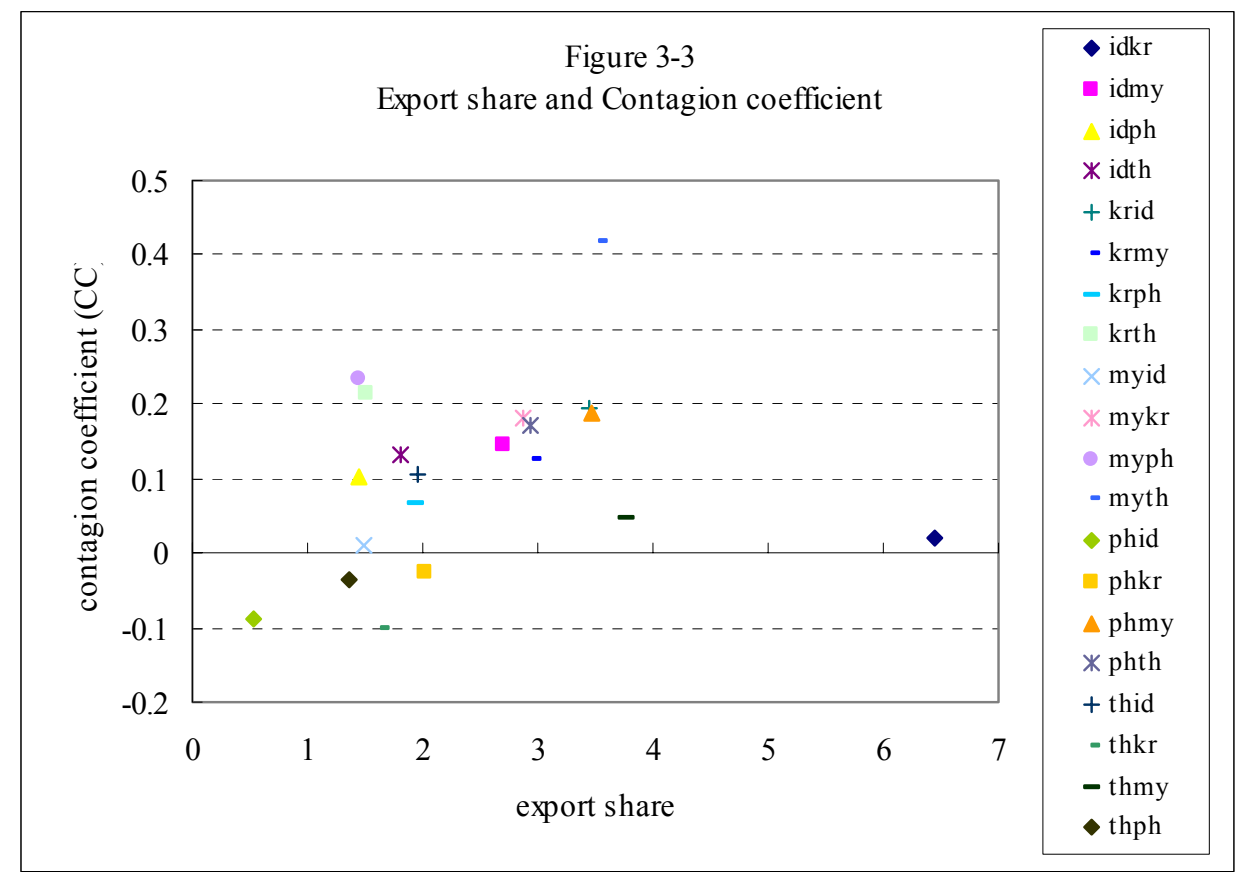




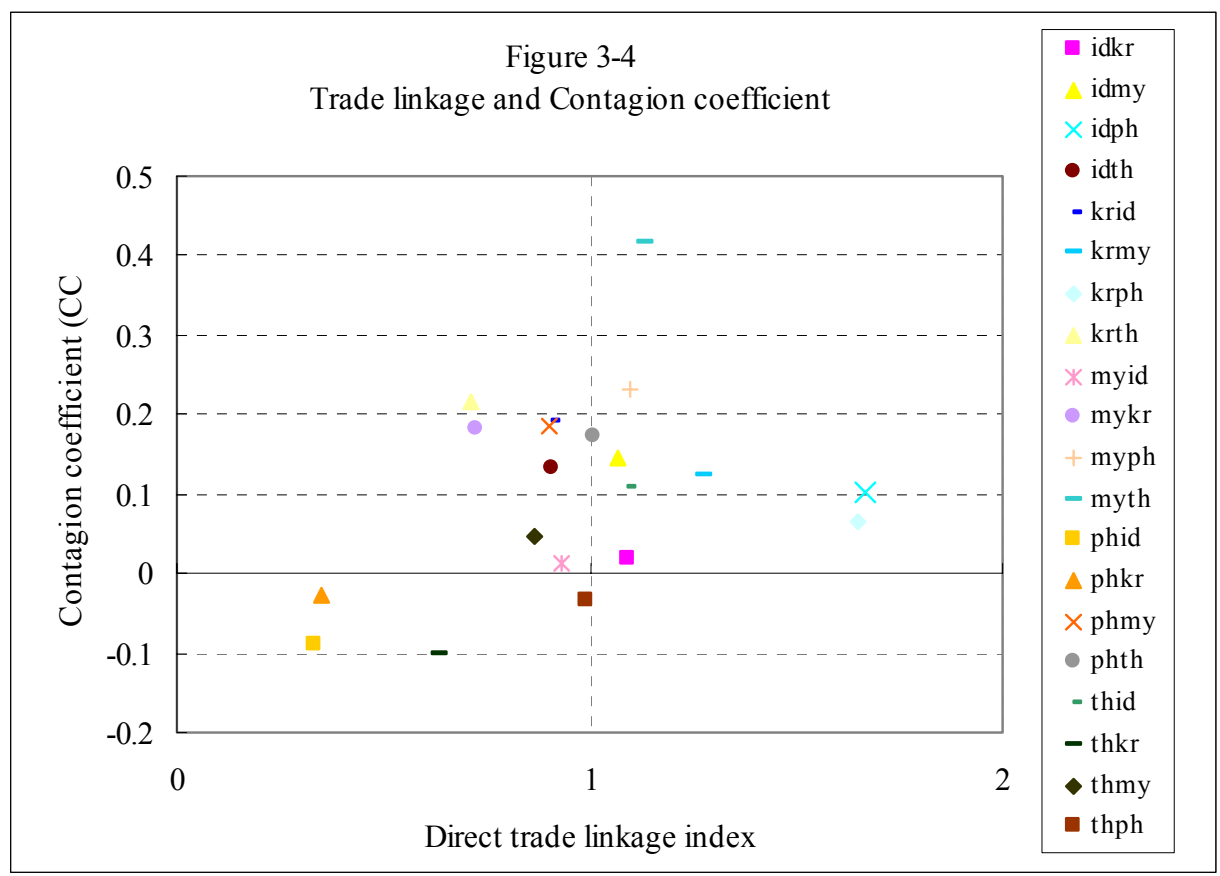




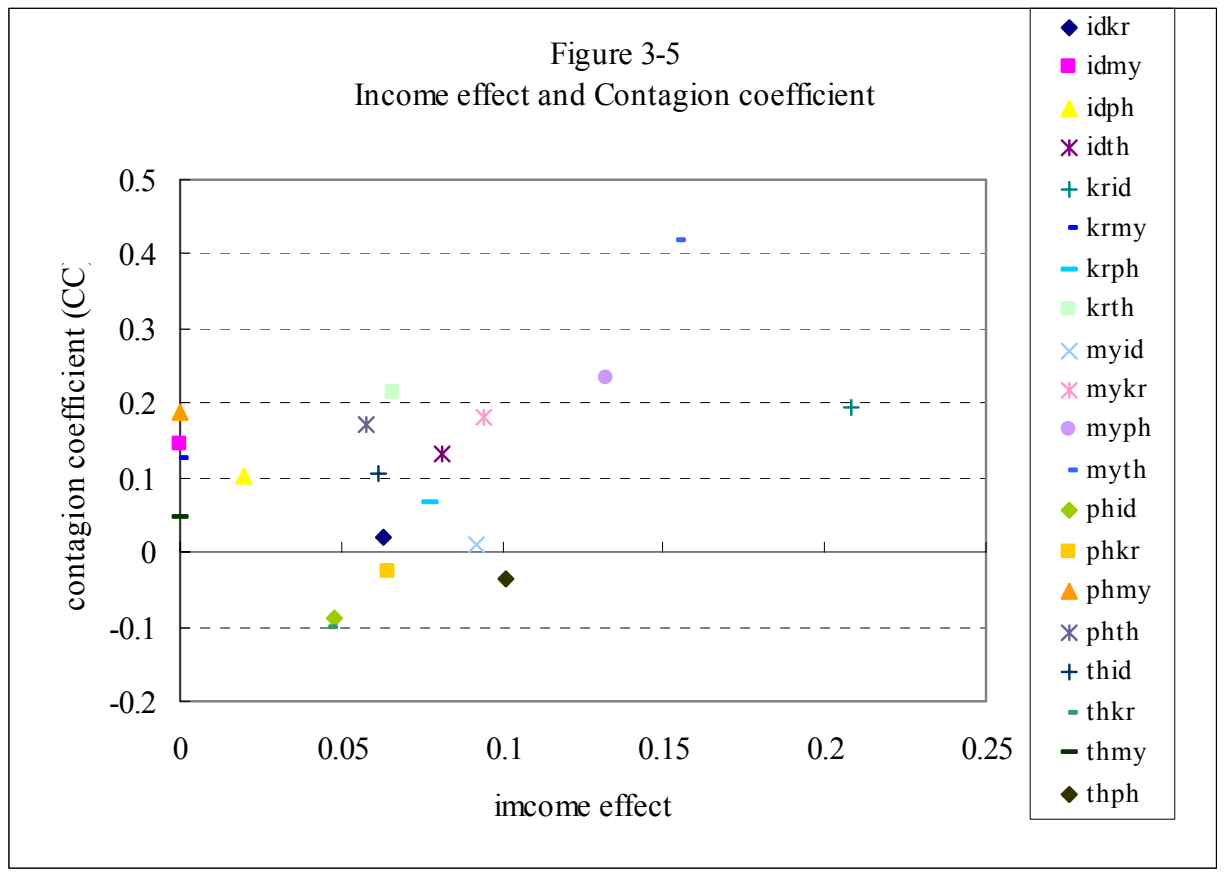




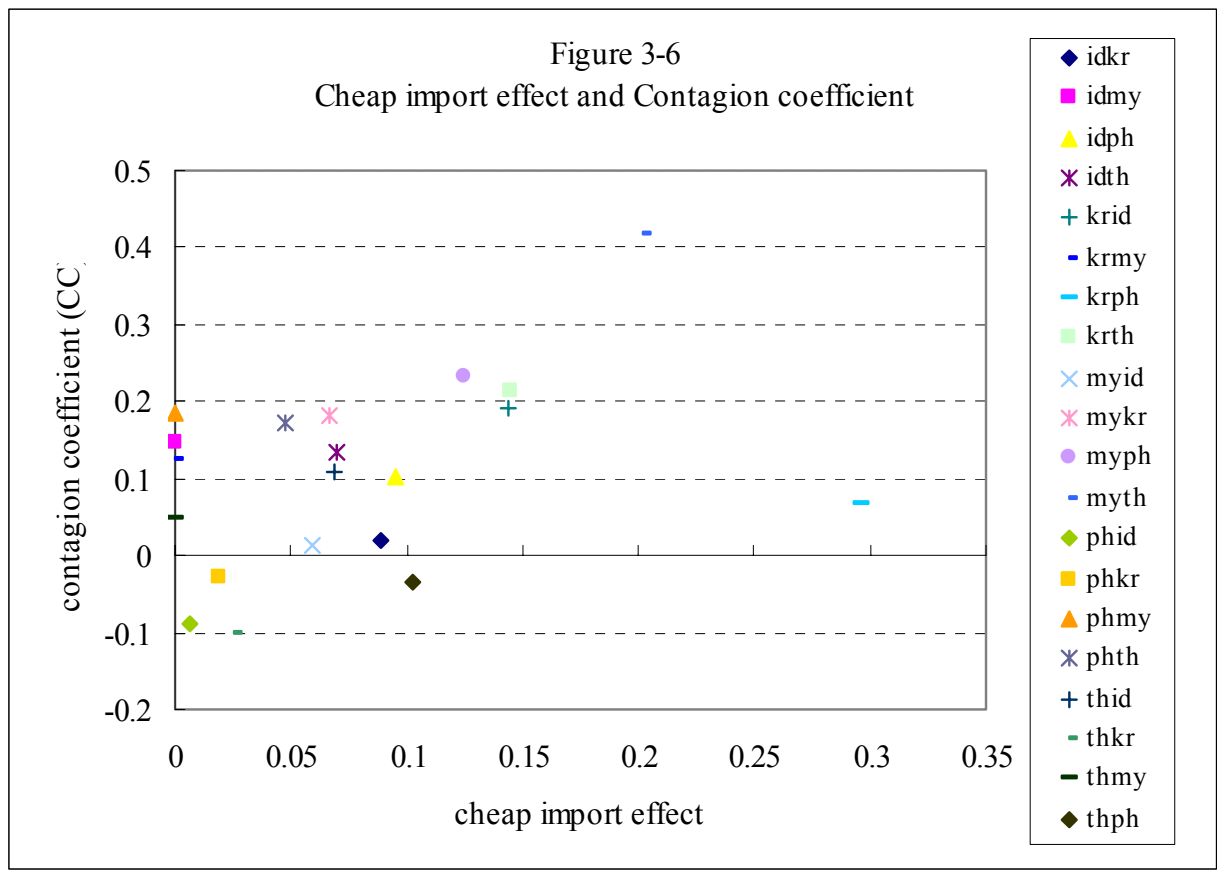


Table 1-1

Weekly Origin (Friday to Friday change), July 1997-January 19

\begin{tabular}{|l|c|c|}
\hline Week & Origin & $\begin{array}{c}\text { devaluation } \\
\text { rate(\%) }\end{array}$ \\
\hline \hline July-1 & TH & -10.11 \\
July-2 & PH & -7.95 \\
July-4 & TH & -5.75 \\
\hline August-3 & ID & -10.13 \\
August-4 & TH & -4.52 \\
August-5 & ID & -7.51 \\
\hline September-1 & TH & -9.40 \\
September-3 & PH & -4.81 \\
\hline October-1 & ID & -13.84 \\
October-5 & TH & -5.99 \\
\hline November-2 & TH & -4.94 \\
November-3 & KR & -4.85 \\
November-4 & KR & -8.13 \\
\hline December-1 & ID & -7.76 \\
December-2 & ID & -32.93 \\
\hline January-1 & KR & -17.63 \\
January-2 & ID & -18.32 \\
January-4 & ID & -57.18 \\
\hline
\end{tabular}

Notes : Authors' calculation.

Data source: Datastream 
Table 1-2

Daily Origin of Exchange Rate, July 1997-March 1999

\begin{tabular}{|c|c|c|c|c|c|c|c|c|c|c|c|c|c|c|}
\hline & & & Origin & $\begin{array}{c}\text { devaluation } \\
\text { rate }(\%)\end{array}$ & & & & Origin & $\begin{array}{c}\text { devaluation } \\
\text { rate }(\%)\end{array}$ & & & & Origin & $\begin{array}{c}\text { devaluation } \\
\text { rate }(\%)\end{array}$ \\
\hline 1997 & 7 & 2 & $\overline{\mathrm{TH}}$ & -3.40 & 1997 & 12 & 11 & KR & -8.02 & 1998 & 3 & $\overline{6}$ & ID & -4.24 \\
\hline 1997 & 7 & 3 & TH & -2.22 & 1997 & 12 & 12 & ID & -10.97 & 1998 & 3 & 9 & ID & -2.40 \\
\hline 1997 & 7 & 4 & $\mathrm{TH}$ & -2.06 & 1997 & 12 & 15 & ID & -6.72 & 1998 & 4 & 16 & ID & -2.23 \\
\hline 1997 & 7 & 14 & $\mathrm{PH}$ & -5.30 & 1997 & 12 & 16 & TH & -3.66 & 1998 & 4 & 21 & $\mathrm{PH}$ & -2.49 \\
\hline 1997 & 7 & 21 & ID & -2.83 & 1997 & 12 & 22 & KR & -10.12 & 1998 & 5 & 6 & ID & -6.12 \\
\hline 1997 & 7 & 23 & $\mathrm{TH}$ & -2.06 & 1997 & 12 & 23 & $\mathrm{KR}$ & -10.12 & 1998 & 5 & 7 & ID & -4.99 \\
\hline 1997 & 8 & 15 & ID & -2.99 & 1997 & 12 & 24 & ID & -4.32 & 1998 & 5 & 13 & ID & -10.37 \\
\hline 1997 & 8 & 18 & ID & -3.23 & 1997 & 12 & 25 & ID & -2.34 & 1998 & 5 & 14 & ID & -3.24 \\
\hline 1997 & 8 & 27 & ID & -2.93 & 1997 & 12 & 31 & $\mathrm{KR}$ & -3.96 & 1998 & 5 & 19 & ID & -12.50 \\
\hline 1997 & 8 & 28 & ID & -3.19 & 1998 & 1 & 2 & ID & -14.38 & 1998 & 5 & 28 & ID & -5.17 \\
\hline 1997 & 9 & 2 & ID & -2.39 & 1998 & 1 & 5 & ID & -13.08 & 1998 & 6 & 10 & ID & -5.08 \\
\hline 1997 & 9 & 3 & $\mathrm{TH}$ & -2.81 & 1998 & 1 & 6 & ID & -11.93 & 1998 & 6 & 11 & ID & -4.66 \\
\hline 1997 & 9 & 4 & TH & -3.74 & 1998 & 1 & 7 & ID & -7.57 & 1998 & 6 & 12 & ID & -4.02 \\
\hline 1997 & 9 & 18 & $\mathrm{PH}$ & -2.06 & 1998 & 1 & 8 & ID & -18.31 & 1998 & 6 & 15 & ID & -4.48 \\
\hline 1997 & 9 & 29 & ID & -2.38 & 1998 & 1 & 12 & $\mathrm{TH}$ & -2.39 & 1998 & 6 & 16 & ID & -4.32 \\
\hline 1997 & 9 & 30 & ID & -2.33 & 1998 & 1 & 16 & ID & -4.01 & 1998 & 6 & 17 & ID & -6.82 \\
\hline 1997 & 10 & 1 & ID & -3.19 & 1998 & 1 & 19 & ID & -7.87 & 1998 & 6 & 29 & MY & -2.01 \\
\hline 1997 & 10 & 3 & ID & -4.32 & 1998 & 1 & 20 & ID & -4.72 & 1998 & 8 & 6 & KR & -3.21 \\
\hline 1997 & 10 & 6 & ID & -2.56 & 1998 & 1 & 21 & ID & -11.10 & 1998 & 8 & 11 & ID & -2.27 \\
\hline 1997 & 10 & 20 & TW & -2.45 & 1998 & 1 & 22 & ID & -12.87 & 1998 & 9 & 8 & ID & -3.44 \\
\hline 1997 & 11 & 20 & KR & -5.52 & 1998 & 1 & 23 & ID & -12.77 & 1998 & 9 & 9 & ID & -2.22 \\
\hline 1997 & 11 & 25 & KR & -2.24 & 1998 & 1 & 26 & ID & -3.85 & 1998 & 10 & 27 & ID & -2.08 \\
\hline 1997 & 11 & 28 & KR & -2.92 & 1998 & 2 & 12 & $\overline{M Y}$ & -3.04 & 1998 & 11 & 2 & ID & -2.74 \\
\hline 1997 & 12 & 1 & KR & -2.21 & 1998 & 2 & 13 & ID & -9.30 & 1998 & 11 & 3 & ID & -4.26 \\
\hline 1997 & 12 & 2 & $\mathrm{KR}$ & -2.82 & 1998 & 2 & 16 & ID & -3.99 & 1998 & 11 & 4 & ID & -3.98 \\
\hline 1997 & 12 & 3 & TH & -3.66 & 1998 & 2 & 17 & $\mathrm{KR}$ & -2.17 & 1998 & 12 & 15 & ID & -2.29 \\
\hline 1997 & 12 & 8 & $\mathrm{KR}$ & -5.39 & 1998 & 2 & 23 & ID & -2.62 & 1998 & 1 & 13 & ID & -3.84 \\
\hline 1997 & 12 & 9 & $\mathrm{KR}$ & -6.88 & 1998 & 3 & 4 & ID & -3.31 & 1999 & 1 & 14 & ID & -2.08 \\
\hline 1997 & 12 & 10 & KR & -6.73 & 1998 & 3 & 5 & ID & -6.84 & 1999 & 3 & 11 & ID & -2.17 \\
\hline
\end{tabular}

Notes: Authors' calculation.

Data source: Datastream 
Table 1-3

Daily Origin of Stock Price, January 1994-June 1999

\begin{tabular}{|c|c|c|c|c|c|c|c|c|c|c|c|c|c|c|}
\hline & & & origin & \begin{tabular}{|c|} 
devaluation \\
rate $(\%)$
\end{tabular} & & & & origin & \begin{tabular}{|c|} 
devaluation \\
rate $(\%)$
\end{tabular} & & & & origin & $\begin{array}{c}\text { devaluation } \\
\text { rate }(\%)\end{array}$ \\
\hline 1994 & $\bar{~} 1$ & 1011 & $\overline{\mathrm{cml}}$ & -3.38 & 1999 & 8 & 29 & id & -4.75 & $\begin{array}{l}1998 \\
\end{array}$ & $\overline{5}$ & 6 & id & $\begin{array}{c}-3.26 \\
\end{array}$ \\
\hline 1994 & 1 & 12 & $\mathrm{ml}$ & -5.07 & 1997 & 9 & 2 & tw & -2.46 & 1998 & 5 & 11 & $\mathrm{kr}$ & -2.10 \\
\hline 1994 & 1 & 13 & $\mathrm{ml}$ & -4.25 & 1997 & 9 & 3 & $\mathrm{ml}$ & -3.42 & 1998 & 5 & 12 & $\mathrm{kr}$ & -2.52 \\
\hline 1994 & 1 & 14 & tw & -2.39 & 1997 & 9 & 4 & $\mathrm{ml}$ & -2.92 & 1998 & 5 & 13 & id & -3.24 \\
\hline 1994 & 1 & 18 & th & -2.15 & 1997 & 9 & 12 & id & -2.11 & 1998 & 5 & 14 & th & -2.18 \\
\hline 1994 & 1 & 20 & th & -2.18 & 1997 & 9 & 18 & $\mathrm{ml}$ & -2.17 & 1998 & 5 & 18 & id & -2.38 \\
\hline 1994 & 1 & 25 & $\mathrm{ml}$ & -2.64 & 1997 & 9 & 22 & $\mathrm{ml}$ & -2.32 & 1998 & 5 & 20 & th & -2.59 \\
\hline 1994 & 2 & 7 & th & -3.86 & 1997 & 9 & 23 & $\mathrm{kr}$ & -2.00 & 1998 & 5 & 25 & $\mathrm{kr}$ & -3.73 \\
\hline 1994 & 2 & 14 & tw & -2.22 & 1997 & 10 & 3 & id & -2.26 & 1998 & 5 & 26 & $\mathrm{kr}$ & -4.84 \\
\hline 1994 & 2 & 28 & tw & -2.47 & 1997 & 10 & 8 & $\mathrm{kr}$ & -2.04 & 1998 & 5 & 29 & th & -2.01 \\
\hline 1994 & 3 & 1 & $\mathrm{ph}$ & -2.75 & 1997 & 10 & 16 & $\mathrm{kr}$ & -2.56 & 1998 & 6 & 1 & tw & -2.66 \\
\hline 1994 & 3 & 2 & $\mathrm{ph}$ & -2.42 & 1997 & 10 & 17 & tw & -2.11 & 1998 & 6 & 2 & th & -3.00 \\
\hline 1994 & 3 & 4 & $\mathrm{ph}$ & -2.39 & 1997 & 10 & 20 & tw & -4.36 & 1998 & 6 & 11 & $\mathrm{ph}$ & -2.52 \\
\hline 1994 & 3 & 9 & $\mathrm{ph}$ & -2.61 & 1997 & 10 & 24 & $\mathrm{ml}$ & -2.59 & 1998 & 6 & 12 & $\mathrm{kr}$ & -4.31 \\
\hline 1994 & 3 & 22 & id & -2.02 & 1997 & 10 & 27 & $\mathrm{kr}$ & -4.46 & 1998 & 6 & 15 & $\mathrm{kr}$ & -4.55 \\
\hline 1994 & 10 & 6 & tw & -2.85 & 1997 & 10 & 29 & th & -3.54 & 1998 & 6 & 16 & $\mathrm{kr}$ & -3.78 \\
\hline 1994 & 10 & 11 & tw & -4.27 & 1997 & 10 & 30 & $\mathrm{kr}$ & -3.17 & 1998 & 7 & 10 & $\mathrm{ml}$ & -2.97 \\
\hline 1994 & 11 & 1 & tw & -3.17 & 1997 & 10 & 31 & $\mathrm{kr}$ & -3.11 & 1998 & 7 & 13 & $\mathrm{ml}$ & -2.38 \\
\hline 1994 & 11 & 23 & th & -3.43 & 1997 & 11 & 7 & $\mathrm{kr}$ & -2.31 & 1998 & 7 & 22 & $\mathrm{ml}$ & -2.07 \\
\hline 1995 & 1 & 12 & th & -2.12 & 1997 & 11 & 11 & id & -2.29 & 1998 & 7 & 23 & $\mathrm{kr}$ & -2.39 \\
\hline 1995 & 1 & 13 & $\mathrm{ph}$ & -3.19 & 1997 & 11 & 17 & $\mathrm{kr}$ & -2.23 & 1998 & 7 & 29 & $\mathrm{ml}$ & -2.84 \\
\hline 1995 & 1 & 23 & th & -2.89 & 1997 & 11 & 18 & $\mathrm{ml}$ & -3.90 & 1998 & 8 & 4 & $\mathrm{ph}$ & -2.13 \\
\hline 1995 & 2 & 27 & ph & -2.08 & 1997 & 11 & 19 & $\mathrm{ml}$ & -3.44 & 1998 & 8 & 5 & id & -3.06 \\
\hline 1995 & 4 & 17 & tw & -2.31 & 1997 & 11 & 20 & $\mathrm{ml}$ & -7.23 & 1998 & 8 & 6 & id & -2.42 \\
\hline 1995 & 7 & 19 & tw & $\begin{array}{l}-2.53 \\
\end{array}$ & 1997 & 11 & 21 & id & -2.27 & 1998 & 8 & 10 & $\mathrm{ml}$ & -2.47 \\
\hline 1995 & 7 & 20 & tw & -2.62 & 1997 & 11 & 24 & $\mathrm{kr}$ & -4.85 & 1998 & 8 & 11 & $\mathrm{ml}$ & -3.92 \\
\hline 1995 & 8 & 9 & tw & -2.26 & 1997 & 11 & 25 & $\mathrm{kr}$ & -3.59 & 1998 & 8 & 12 & $\mathrm{ph}$ & -3.85 \\
\hline 1995 & 8 & 11 & tw & -2.74 & 1997 & 11 & 26 & $\mathrm{ml}$ & -2.88 & 1998 & 8 & 13 & $\mathrm{ml}$ & -2.72 \\
\hline 1995 & 11 & 20 & $\mathrm{ph}$ & -2.04 & 1997 & 11 & 28 & $\mathrm{kr}$ & -3.63 & 1998 & 8 & 17 & $\mathrm{ml}$ & -2.45 \\
\hline 1995 & 12 & 14 & $\mathrm{kr}$ & -2.12 & 1997 & 12 & 1 & $\mathrm{kr}$ & -3.82 & 1998 & 8 & 18 & $\mathrm{kr}$ & -2.08 \\
\hline 1995 & 12 & 18 & $\mathrm{kr}$ & -2.32 & 1997 & 12 & 2 & $\mathrm{kr}$ & -3.91 & 1998 & 8 & 21 & $\mathrm{ml}$ & -2.43 \\
\hline 1996 & 1 & 5 & tw & $\begin{array}{l}-3.43 \\
\end{array}$ & 1997 & 12 & 9 & $\mathrm{kr}$ & -3.00 & 1998 & 8 & 24 & id & -3.31 \\
\hline 1996 & 1 & 29 & tw & -2.70 & 1997 & 12 & 12 & $\mathrm{kr}$ & -5.24 & 1998 & 8 & 25 & id & -2.02 \\
\hline 1996 & 5 & 20 & tw & -2.39 & 1997 & 12 & 15 & id & -6.21 & 1998 & 8 & 27 & $\mathrm{ml}$ & -2.01 \\
\hline 1996 & 7 & 29 & id & -2.31 & 1997 & 12 & 16 & $\mathrm{ml}$ & -2.68 & 1998 & 8 & 28 & $\mathrm{ph}$ & -3.75 \\
\hline 1996 & 10 & 4 & th & -2.05 & 1997 & 12 & 23 & $\mathrm{kr}$ & -4.23 & 1998 & 9 & 10 & ph & -3.17 \\
\hline 1996 & 10 & 8 & th & -4.19 & 1997 & 12 & 24 & $\mathrm{kr}$ & -4.26 & 1998 & 9 & 11 & $\mathrm{ph}$ & -2.24 \\
\hline 1996 & 10 & 28 & $\mathrm{ph}$ & -2.63 & 1997 & 12 & 25 & $\mathrm{kr}$ & -2.29 & 1998 & 9 & 15 & id & -4.88 \\
\hline 1997 & 1 & 7 & $\mathrm{kr}$ & -2.24 & 1998 & 1 & 5 & $\mathrm{ml}$ & -2.86 & 1998 & 9 & 17 & id & -2.28 \\
\hline 1997 & 2 & 4 & th & -3.43 & 1998 & 1 & 6 & $\mathrm{ml}$ & -3.44 & 1998 & 9 & 18 & id & -3.56 \\
\hline 1997 & 2 & 14 & th & -2.15 & 1998 & 1 & 8 & $\mathrm{ph}$ & -3.96 & 1998 & 9 & 21 & id & -4.75 \\
\hline 1997 & 3 & 4 & th & -2.28 & 1998 & 1 & 9 & $\mathrm{ph}$ & -6.21 & 1998 & 9 & 22 & $\mathrm{ph}$ & -2.22 \\
\hline 1997 & 3 & 7 & th & -4.56 & 1998 & 1 & 22 & $\mathrm{ph}$ & -3.08 & 1998 & 10 & 2 & tw & -2.64 \\
\hline 1997 & 3 & 24 & tw & -2.41 & 1998 & 2 & 5 & th & -2.19 & 1998 & 10 & 27 & $\mathrm{kr}$ & -2.30 \\
\hline 1997 & 4 & 8 & ph & -2.24 & 1998 & 2 & 11 & id & -3.41 & 1998 & 11 & 9 & ph & -2.30 \\
\hline 1997 & 4 & 29 & $\mathrm{ph}$ & -2.62 & 1998 & 2 & 12 & id & -6.18 & 1998 & 11 & 10 & $\mathrm{ph}$ & -3.26 \\
\hline 1997 & 4 & 30 & $\mathrm{ph}$ & -2.49 & 1998 & 2 & 13 & id & -2.60 & 1998 & 11 & 11 & th & -3.62 \\
\hline 1997 & 5 & 15 & th & -2.54 & 1998 & 2 & 16 & $\mathrm{kr}$ & -3.77 & 1998 & 11 & 13 & th & -2.69 \\
\hline 1997 & 5 & 16 & th & -2.46 & 1998 & 2 & 17 & $\mathrm{kr}$ & -2.49 & 1998 & 11 & 25 & id & -2.96 \\
\hline 1997 & 5 & 19 & $\mathrm{ph}$ & -2.08 & 1998 & 3 & 5 & $\mathrm{kr}$ & -2.66 & 1998 & 12 & 3 & th & -2.82 \\
\hline 1997 & 7 & 9 & ph & -2.56 & 1998 & 3 & 6 & $\mathrm{kr}$ & -2.55 & 1998 & 12 & 4 & th & -2.18 \\
\hline 1997 & 7 & 10 & $\mathrm{ph}$ & -2.74 & 1998 & 3 & 9 & $\mathrm{kr}$ & -2.86 & 1998 & 12 & 17 & $\mathrm{kr}$ & -2.66 \\
\hline 1997 & 8 & 5 & $\mathrm{ml}$ & -2.55 & 1998 & 3 & 30 & $\mathrm{kr}$ & -2.21 & 1999 & 1 & 5 & tw & -2.13 \\
\hline 1997 & 8 & 7 & id & -2.16 & 1998 & 4 & 1 & $\mathrm{kr}$ & -2.00 & 1999 & 1 & 26 & th & -2.37 \\
\hline 1997 & 8 & 15 & id & -2.76 & 1998 & 4 & 2 & $\mathrm{kr}$ & -2.49 & 1999 & 2 & 8 & $\mathrm{ml}$ & -3.78 \\
\hline 1997 & 8 & 18 & id & -2.74 & 1998 & 4 & 3 & $\mathrm{kr}$ & -3.50 & 1999 & 2 & 9 & $\mathrm{kr}$ & -2.45 \\
\hline 1997 & 8 & 20 & id & -2.09 & 1998 & 4 & 16 & $\mathrm{ml}$ & -2.07 & 1999 & 2 & 10 & th & -2.07 \\
\hline 1997 & 8 & 22 & id & -2.18 & 1998 & 4 & 23 & $\mathrm{kr}$ & -2.43 & 1999 & 2 & 19 & $\mathrm{kr}$ & -2.02 \\
\hline 1997 & 8 & 25 & id & -3.81 & 1998 & 4 & 29 & id & -2.35 & 1999 & 5 & 13 & $\mathrm{kr}$ & -2.73 \\
\hline 1997 & 8 & 26 & th & -3.99 & 1998 & 5 & 1 & id & -2.12 & 1999 & 5 & 17 & $\mathrm{kr}$ & -2.32 \\
\hline 1997 & 8 & 27 & th & -2.33 & 1998 & 5 & 4 & $\mathrm{kr}$ & -3.20 & 1999 & 5 & 26 & th & -2.59 \\
\hline 1997 & 8 & 28 & $\mathrm{ph}$ & -5.40 & 1998 & 5 & 5 & id & -2.00 & & & & & \\
\hline
\end{tabular}

Notes : Authors' calculation. 
Table 2

News and Events (Daily Origin of Exchange Rate) July 1997-June 1999

\begin{tabular}{|c|c|c|c|c|}
\hline & & & Origin & News \\
\hline 1997 & 7 & 2 & TH & Devaluing baht. \\
\hline 1997 & 7 & 3 & TH & Thai credit agency downgrades most ratings on devaluation. IMF welcomes Thai baht float. \\
\hline 1997 & 7 & 4 & TH & Thai central bank sets baht-dollar reference rate at 28.189 . \\
\hline 1997 & 7 & 14 & $\mathrm{PH}$ & Philippine bankers group lifts volatility band on peso trading. \\
\hline 1997 & 7 & 21 & ID & Indonesian Minister of Finance says Indonesia won't change Rupiah's managed float. \\
\hline 1997 & 7 & 23 & TH & Thai finance minister says no need for financial aid from Japan and IMF. \\
\hline 1997 & 8 & 15 & ID & Indonesian central bank called an emergency meeting with country's largest banks. \\
\hline 1997 & 8 & 18 & ID & Bank Indonesia raises SBI interest rate. \\
\hline 1997 & 8 & 27 & ID & Many indonesian not making new loans because fear of high interest rate. \\
\hline 1997 & 8 & 28 & ID & Suharto worried high interest rates hurt economy. \\
\hline 1997 & 9 & 2 & ID & Inflation rate rises to $5.7 \%$, eight-month high. \\
\hline 1997 & 9 & 3 & TH & Tahi won't seek increase in IMF package. \\
\hline 1997 & 9 & 4 & TH & Thai finance minister syas Government won't intervene in market. \\
\hline 1997 & 9 & 18 & $\mathrm{PH}$ & The EYCO group of companies, Appliance Maker, to stop debt payments. \\
\hline 1997 & 9 & 29 & ID & S\&P degrades Malaysia, and will degrade Indonesia. \\
\hline 1997 & 10 & 1 & ID & Tradeand industry minister said Rupiah decline won't boost exports. \\
\hline 1997 & 10 & 3 & ID & Bank Indonesia to provide Swaps facilities for exporters. \\
\hline 1997 & 10 & 6 & ID & Suharto calls emergency meeting with top economic ministers. \\
\hline 1997 & 10 & 20 & TW & Taiwan authority won't support Taiwaniese dollar. \\
\hline 1997 & 11 & 20 & KR & South Korean finance minister to resign due to a failure in the passage of financial reform bills. \\
\hline 1997 & 11 & 25 & KR & Korea asks IMF for standby credit, Finance minister says. \\
\hline 1997 & 11 & 28 & KR & Korean Oct. CA deficit widened to $\$ 680.6 \mathrm{mln}$ from $\$ 498.4 \mathrm{mln}$. \\
\hline 1997 & 12 & 1 & KR & Korea and IMF at odds over bailout. \\
\hline 1997 & 12 & 2 & KR & Korean stocks fell for a ninth day as the abrupt closure of 9 merchant banks. \\
\hline 1997 & 12 & 3 & ID & Indonesia may be headed for double-digit inflation this year. \\
\hline 1997 & 12 & 9 & $\mathrm{KR}$ & Korea may shut down 2 commercial banks as part of IMF bailout. \\
\hline 1997 & 12 & 16 & TH & Thai currency reserves may be halved. \\
\hline 1997 & 12 & 22 & $\mathrm{KR}$ & Korean Crisis deepens as Moody's Cuts rating. \\
\hline 1997 & 12 & 23 & KR & Korea debt payment's delay mulled by foreign banks. \\
\hline 1997 & 12 & 24 & ID & Indonesia's foreign debt payment may reach 323 trillion rupiah. \\
\hline 1997 & 12 & 31 & KR & Korea's Total external debt estimated at $\$ 156.9$ bln, up $\$ 41$ bln. \\
\hline 1998 & 1 & 2 & ID & Indonesian State Banks to Merge. \\
\hline 1998 & 1 & 5 & ID & Indonesia to increase generic Drug prices $15 \%$ in April. \\
\hline 1998 & 1 & 6 & ID & Indonesia's December inflation seen rising $2 \%$ from November. \\
\hline 1998 & 1 & 7 & ID & Indonesia sees inflation of 9\% in fiscal 1998-1999. \\
\hline 1998 & 1 & 8 & ID & US official Rubin says Indonesia must do more to meet IMF goals. \\
\hline 1998 & 1 & 12 & $\mathrm{TH}$ & Thai Govt to brief Creditors of closed 56 insolvent finance firms . \\
\hline 1998 & 1 & 16 & ID & Suharto's promises to revise the budget fail to impress. \\
\hline 1998 & 1 & 19 & ID & Indonesia reserves fall $8.2 \%$ to $\$ 20.38$ bln in month to Jan. 15 . \\
\hline 1998 & 1 & 20 & ID & Bank International INdonesia's credit rating may be cut by S\&P. \\
\hline 1998 & 1 & 21 & ID & Indonesia state ratings company cut ratings on 17 companies. \\
\hline 1998 & 1 & 23 & ID & Indonesia's Budget Plan for 1998 revised. \\
\hline 1998 & 1 & 26 & ID & Moody's raises specter of indonesia corporate debt moratorium. \\
\hline
\end{tabular}

Source: Bloomberg 
Table 2(continued)

News and Events (Daily Origin) July 1997-June, 1999

\begin{tabular}{|c|c|c|c|c|}
\hline & & & Origin & News \\
\hline 1998 & 2 & 12 & MY & Foreign reserve in January down. \\
\hline 1998 & 2 & 13 & ID & Rubin Concerned Over Pegging Rupiah to Dollar. \\
\hline 1998 & 2 & 16 & ID & Camdessus Says It's Too Soon for Indonesian Currency Peg. \\
\hline 1998 & 2 & 17 & KR & Korea accepts Labor Law revisions. \\
\hline 1998 & 3 & 4 & ID & GS prospects the Pegging Rupiah to Dollar. \\
\hline 1998 & 3 & 5 & ID & IMF Officials Say Indonesia Aid Payment Likely to Be Postponed. \\
\hline 1998 & 3 & 6 & ID & Indonesia's Finance Minister Warns of Consequences if IMF Aid Withheld. \\
\hline 1998 & 3 & 9 & ID & IMF Says Indonesia Won't Receive Next Loan Before April. \\
\hline 1998 & 4 & 16 & ID & Indonesia's Suharto Pledges to Adhere to Reforms. \\
\hline 1998 & 4 & 21 & $\mathrm{PH}$ & Philippines Polls Tainted By Fears of Fraud. \\
\hline 1998 & 5 & 6 & ID & Indonesian Fuel Prices to Rise Tomorrow. \\
\hline 1998 & 5 & 7 & ID & Palm Oil Rises to Record High on Weak Ringgit, Likely Shortage. \\
\hline 1998 & 5 & 13 & ID & Students burn effigies of President Suharto in the capital and surging prices trigger riots. \\
\hline 1998 & 5 & 14 & ID & Thousands Protest Indonesia University Killings, a second day of violence in Jakarta. \\
\hline 1998 & 5 & 19 & ID & House of Representatives calls for the resignation of President Suharto. \\
\hline 1998 & 5 & 28 & ID & President Suharto and IMF did not reach agreement on conditions for IMF support. \\
\hline 1998 & 6 & 10 & ID & IMF official arrive in Jakarta for review of economic targets under the IMF loan disbursement plan \\
\hline 1998 & 6 & 11 & ID & Indonesian Banks Cut Deposit Rates Yesterday. \\
\hline 1998 & 6 & 12 & ID & Indonesian Army Parliamentary Seats to Be Cut. \\
\hline 1998 & 6 & 16 & ID & IMF Sees Indonesian Deficit of More Than $4 \%$ of GDP. \\
\hline 1998 & 6 & 17 & ID & Indonesian Banks' Bad Loans Surged to $25 \%$ at End April. \\
\hline 1998 & 6 & 29 & MY & Malaysia Plans New Ways to Plug Ringgit Outflow. \\
\hline 1998 & 8 & 6 & KR & Korea's Big Five Cheabols need debt payment amount to 28 billion of USD. \\
\hline 1998 & 8 & 11 & ID & Indonesia Refutes Report That it Failed to Make Debt Paymen. \\
\hline 1998 & 9 & 8 & ID & Students descended on House of Representatives calling for resignation of President B.J. Habibie. \\
\hline 1998 & 9 & 9 & ID & Indonesian Military Breaks Up Student Protest With Tear Gas. \\
\hline 1998 & 10 & 27 & ID & Indonesia Mulling Return to Currency Band System. \\
\hline 1998 & 11 & 2 & ID & Indonesia August Trade Surplus Narrows to $\$ 1.85$ Billion. \\
\hline 1998 & 11 & 3 & ID & Indonesian Companies Unlikely to Get Large Debt Write-offs. \\
\hline 1998 & 11 & 4 & ID & Indonesian Panel Says Security Agents Linked to Riots in May. \\
\hline 1998 & 12 & 15 & ID & Indonesia Sees Tourism Revenues about half of targeting. \\
\hline 1999 & 1 & 13 & ID & Indonesia Unveils Law to Narrow Central Bank's Role. \\
\hline 1999 & 3 & 11 & ID & Indonesia Mulls Merger Of five of the largest private banks. \\
\hline
\end{tabular}

Source: Bloomberg 
Table 3-1 CC(t,i) of Exchange Rate

1997:1-1999:7

\begin{tabular}{|c|c|c|c|c|c|c|}
\hline \multirow{2}{*}{$\begin{array}{l}\text { Origin } \\
\text { (nob) }\end{array}$} & \multicolumn{5}{|c|}{ Affected } & \multirow[b]{2}{*}{ Thailand } \\
\hline & Indonesia & Korea & Malaysia & Philippines & Taiwan & \\
\hline \multicolumn{2}{|c|}{ ID (July-Dec 1997) (16) } & 0.056 & $0.290 * * *$ & $0.193 * *$ & 0.012 & $0.303 * * *$ \\
\hline t-stat & & 1.138 & 4.685 & 2.858 & 1.155 & 6.349 \\
\hline \multicolumn{2}{|c|}{ ID (Oct-Dec 1997) (8) } & 0.094 & $0.256^{*}$ & $0.249 *$ & $0.036^{*}$ & $0.332 * * *$ \\
\hline t-stat & & 1.025 & 2.079 & 1.868 & 1.873 & 3.508 \\
\hline \multicolumn{2}{|c|}{ ID (Jan-June 1998) (32) } & $0.061 * *$ & $0.121 * *$ & $0.090 * * *$ & $0.023 * *$ & $0.069 * * *$ \\
\hline t-stat & & 2.119 & 2.576 & 3.244 & 2.083 & 2.938 \\
\hline \multicolumn{2}{|c|}{ ID (after July 1998) (12) } & $0.063^{*}$ & 0.004 & -0.079 & -0.023 & 0.038 \\
\hline t-stat & & 2.158 & 0.178 & -1.527 & -1.330 & 0.945 \\
\hline $\mathrm{KR}(14)$ & 0.193 & & $0.124 * *$ & $0.066 * *$ & 0.016 & $0.215 * * *$ \\
\hline t-stat & 1.067 & & 2.643 & 2.283 & 0.795 & 3.593 \\
\hline $\operatorname{ML}(2)$ & 0.012 & 0.181 & & 0.233 & $0.041^{* *}$ & 0.418 \\
\hline t-stat & 0.024 & 1.032 & & 1.552 & 5.490 & 2.388 \\
\hline $\mathrm{PH}(3)$ & -0.089 & -0.027 & 0.186 & & -0.006 & 0.173 \\
\hline t-stat & -0.598 & -0.535 & 1.083 & & -0.480 & 1.609 \\
\hline TH(7) & 0.183 & -0.322 & 0.064 & 0.085 & 0.057 & \\
\hline t-stat & 1.241 & -1.080 & 0.396 & 0.461 & 1.329 & \\
\hline TW(1) & 0.286 & 0.218 & 0.770 & 0.047 & & 0.552 \\
\hline t-stat & - & - & - & - & & - \\
\hline
\end{tabular}

Note: Values tabulated are Contagion coefficients and t-statistics, calculated under the null hypothesis of cc equals zero; there exists no significant high frequency contagion from the origin to affected country.

$* * *, * *$ and $*$ indicate significant at $1 \%, 5 \%$ and $10 \%$, respectively. 
Table 3-2 CC(t,i) of Stock Price

Full sample(1994:1-1999:7)

\begin{tabular}{|c|c|c|c|c|c|c|}
\hline \multirow{2}{*}{$\begin{array}{l}\text { Origin } \\
\text { (nob) }\end{array}$} & \multicolumn{6}{|c|}{ Affected } \\
\hline & Indonesia & Korea & Malaysia & Philippines & Taiwan & Thailand \\
\hline ID(30) & & $0.170 * *$ & $0.276^{* * *}$ & 0.078 & 0.066 & $0.187 * * *$ \\
\hline t-stat & & 2.526 & 3.790 & 0.687 & 1.473 & 2.813 \\
\hline $\mathrm{KR}(47)$ & 0.011 & & $0.215^{* * *}$ & $0.114 * *$ & 0.031 & $0.286^{* * *}$ \\
\hline t-stat & 0.192 & & 3.731 & 2.378 & 0.781 & 6.181 \\
\hline ML(29) & $0.227 * * *$ & 0.049 & & $0.276^{* * *}$ & $0.139 * * *$ & $0.153 * *$ \\
\hline t-stat & 2.929 & 0.472 & & 3.752 & 2.943 & 2.118 \\
\hline $\mathrm{PH}(27)$ & $0.266^{* *}$ & 0.171 & $0.188^{*}$ & & 0.076 & -0.067 \\
\hline t-stat & 2.543 & 1.503 & 2.009 & & 1.310 & -0.490 \\
\hline TW(22) & 0.074 & 0.086 & 0.112 & $0.124 *$ & & $0.153 *$ \\
\hline t-stat & 1.001 & 0.874 & 1.273 & 1.901 & & 1.885 \\
\hline TH(33) & $0.132 * *$ & 0.027 & 0.062 & $0.205 * * *$ & 0.044 & \\
\hline t-stat & 2.204 & 0.340 & 0.645 & 2.850 & 0.736 & \\
\hline
\end{tabular}

Note: Values tabulated are Contagion coefficients and t-statistics, calculated under the null hypothesis of cc equals zero; there exists no significant high frequency contagion from the origin to affected country.

$* * *, * *$ and $*$ indicate significant at $1 \%, 5 \%$ and $10 \%$, respectively. 
Table 3-3 CC(t,i) of Stock Price

Before Crises (1994:1-1997:6)

\begin{tabular}{|c|c|c|c|c|c|c|}
\hline \multirow{2}{*}{$\begin{array}{l}\text { Origin } \\
\text { (nob) }\end{array}$} & \multicolumn{5}{|c|}{ Affected } & \multirow[b]{2}{*}{ Thailand } \\
\hline & Indonesia & Korea & Malaysia & Philippines & Taiwan & \\
\hline$\overline{\mathrm{ID}(2)}$ & & $0.409 * * *$ & 0.302 & $0.556^{* *}$ & -0.100 & 0.182 \\
\hline stat & & 40.146 & 1.678 & 6.543 & -0.995 & 0.685 \\
\hline KR(3) & -0.068 & & -0.104 & $-0.086^{*}$ & -0.283 & 0.127 \\
\hline stat & -0.343 & & -0.790 & -2.549 & -2.196 & 1.275 \\
\hline ML(4) & $0.265^{* *}$ & -0.123 & & $0.359^{*}$ & 0.318 & 0.254 \\
\hline stat & 3.680 & -0.532 & & 2.628 & 1.974 & 1.280 \\
\hline $\mathrm{PH}(12)$ & $0.251 * * *$ & 0.095 & $0.188 * *$ & & 0.122 & $0.261 * *$ \\
\hline stat & 4.123 & 0.440 & 2.321 & & 1.178 & 2.813 \\
\hline TW(16) & 0.013 & 0.140 & -0.025 & 0.074 & & 0.136 \\
\hline stat & 0.289 & 1.288 & -0.267 & 1.291 & & 1.439 \\
\hline $\mathrm{TH}(17)$ & $0.155^{*} *$ & 0.028 & $0.226 * *$ & 0.122 & 0.040 & \\
\hline stat & 2.267 & 0.341 & 2.535 & 1.137 & 0.532 & \\
\hline
\end{tabular}

Note: Values tabulated are Contagion coefficients and t-statistics, calculated under the null hypothesis of cc equals zero; there exists no significant high frequency contagion from the origin to affected country.

$* * *, * *$ and $*$ indicate significant at $1 \%, 5 \%$ and $10 \%$, respectively. 
Table 3-4 CC(t,i) of Stock Price After Crises (1997:7-1999:7)

\begin{tabular}{|c|c|c|c|c|c|c|}
\hline \multirow{2}{*}{$\begin{array}{l}\text { Origin } \\
\text { (nob) }\end{array}$} & \multicolumn{5}{|c|}{ Affected } & \multirow[b]{2}{*}{ Thailand } \\
\hline & Indonesia & Korea & Malaysia & Philippines & Taiwan & \\
\hline$\overline{\mathrm{ID}(28)}$ & & $0.153 * *$ & $0.274 * * *$ & 0.044 & 0.077 & $0.187 * *$ \\
\hline stat & & 2.152 & 3.534 & 0.367 & 1.660 & 2.676 \\
\hline KR(44) & 0.017 & & $0.237 * * *$ & $0.128 * *$ & 0.053 & $0.297 * * *$ \\
\hline stat & 0.271 & & 3.963 & 2.525 & 1.313 & 6.094 \\
\hline ML(25) & $0.222 * *$ & 0.076 & & $0.263 * * *$ & $0.111^{* *}$ & $0.136^{*}$ \\
\hline stat & 2.469 & 0.642 & & 3.165 & 2.326 & 1.738 \\
\hline $\mathrm{PH}(15)$ & $0.278 * * *$ & $0.232 * *$ & $0.187 * *$ & & 0.039 & $-0.329^{*}$ \\
\hline stat & 5.127 & 2.352 & 2.301 & & 0.434 & -1.948 \\
\hline TW(6) & 0.238 & -0.058 & 0.478 & 0.256 & & 0.199 \\
\hline stat & 1.605 & -0.409 & 1.263 & 1.901 & & 1.263 \\
\hline $\mathrm{TH}(16)$ & 0.109 & 0.026 & -0.113 & $0.293 * * *$ & 0.049 & \\
\hline stat & 1.060 & 0.185 & -0.689 & 3.144 & 0.502 & \\
\hline
\end{tabular}

Note: Values tabulated are Contagion coefficients and t-statistics, calculated under the null hypothesis of cc equals zero; there exists no significant high frequency contagion from the origin to affected country.

$* * *, * *$ and $*$ indicate significant at $1 \%, 5 \%$ and $10 \%$, respectively. 
Table 4 Results of Dynamic OLS: Exchange Rate

Panel A: all(pooled) origin

\begin{tabular}{lrrrrrr}
\hline & \multicolumn{7}{c}{ Affected countries } \\
\cline { 2 - 7 } & Indonesia & \multicolumn{1}{c}{ Korea } & Malaysia & Philippines & Taiwan & Thailand \\
\hline \hline coefficient & -0.274 & 0.120 & 0.155 & 0.198 & 0.079 & 0.144 \\
replaced s.e & 0.010 & 0.016 & 0.011 & 0.010 & 0.589 & 0.009 \\
replaced t & -26.669 & 7.452 & 13.963 & 18.840 & 0.133 & 16.138 \\
\hline
\end{tabular}

Panel B: Indonesia origin

\begin{tabular}{|c|c|c|c|c|c|c|}
\hline & \multicolumn{6}{|c|}{ Affected countries } \\
\hline & Indonesia & Korea & Malaysia & Philippines & Taiwan & Thailand \\
\hline coefficient & & "-0.113 & 0.028 & 0.044 & 0.020 & $\overline{0.017}$ \\
\hline replaced s.e. & & 0.063 & 0.016 & 0.015 & 0.002 & 0.010 \\
\hline replaced t & & -1.790 & 1.745 & 2.994 & 9.923 & 1.635 \\
\hline
\end{tabular}

Panel C: Korea origin

\begin{tabular}{|c|c|c|c|c|c|c|}
\hline & \multicolumn{6}{|c|}{ Affected countries } \\
\hline & Indonesia & Korea & Malaysia & Philippines & Taiwan & Thailand \\
\hline coefficient & 0.675 & & 0.250 & 0.236 & -0.027 & -1.443 \\
\hline replaced s.e & 0.326 & & 0.046 & 0.363 & 0.499 & 0.227 \\
\hline replaced t & 2.075 & & 5.471 & 0.650 & -0.055 & -6.365 \\
\hline
\end{tabular}


Table 5-1 Results of Dynamic OLS: Stock Price

Panel A: all(pooled) origin, full sample

\begin{tabular}{lrrrrrr}
\hline & \multicolumn{6}{c}{ Affected countries } \\
\cline { 2 - 7 } & Indonesia & \multicolumn{1}{c}{ Korea } & Malaysia & Philippines & Taiwan & Thailand \\
\hline \hline coefficient & 0.493 & -0.053 & 0.650 & 0.425 & 0.076 & 0.253 \\
replaced s.e & 0.009 & 0.011 & 0.008 & 0.007 & 0.003 & 0.010 \\
replaced t & 57.505 & -4.881 & 80.386 & 63.582 & 22.379 & 24.698 \\
\hline
\end{tabular}

Panel B: all(pooled) origin, pre-crisis period

\begin{tabular}{lrrrrrr}
\hline & \multicolumn{7}{c}{ Affected countries } \\
\cline { 2 - 7 } & Indonesia & \multicolumn{1}{c}{ Korea } & \multicolumn{1}{c}{ Malaysia } & Philippines & \multicolumn{1}{c}{ Taiwan } & Thailand \\
\hline \hline coefficient & 0.065 & -0.209 & -0.164 & 0.535 & 0.314 & -0.119 \\
replaced s.e & 0.011 & 0.012 & 0.012 & 0.023 & 0.017 & 0.025 \\
replaced t & 6.039 & -18.192 & -13.920 & 23.532 & 18.246 & -4.850 \\
\hline
\end{tabular}

Panel C: all(pooled) origin, post-crisis period

\begin{tabular}{lrrrrrr}
\hline & \multicolumn{7}{c}{ Affected countries } \\
\cline { 2 - 7 } & Indonesia & \multicolumn{1}{c}{ Korea } & Malaysia & Philippines & Taiwan & Thailand \\
\hline \hline coefficient & 0.525 & -0.058 & 0.685 & 0.387 & 0.025 & 0.271 \\
replaced s.e & 0.019 & 0.025 & 0.016 & 0.010 & 0.004 & 0.015 \\
replaced t & 27.510 & -2.277 & 42.209 & 40.076 & 5.604 & 17.767 \\
\hline
\end{tabular}


Table 5-2 Results of Dynamic OLS: Stock Price

Panel A: Indonesia origin, full sample

\begin{tabular}{|c|c|c|c|c|c|c|}
\hline & \multicolumn{6}{|c|}{ Affected countries } \\
\hline & Indonesia & Korea & Malaysia & Philippines & Taiwan & Thailand \\
\hline coefficient & & $\overline{-0.041}$ & $\overline{c 1.713}$ & 0.680 & $\overline{-0.339}$ & $\overline{-0.502}$ \\
\hline replaced s.e. & & 0.041 & 0.117 & 0.539 & 0.184 & 0.652 \\
\hline replaced t & & -1.006 & 14.617 & 1.261 & -1.848 & -0.770 \\
\hline
\end{tabular}

Panel B: Indonesia origin, pre-crisis period

\begin{tabular}{|c|c|c|c|c|}
\hline & \multicolumn{4}{|c|}{ Affected countries } \\
\hline & Indonesia $\quad$ Korea & Malaysia Philippines & Taiwan & Thailand \\
\hline $\begin{array}{l}\text { coefficient } \\
\text { replaced s.e. } \\
\text { replaced t }\end{array}$ & & & & \\
\hline
\end{tabular}

Panel C: Indonesia origin, post-crisis period

\begin{tabular}{|c|c|c|c|c|c|c|}
\hline & \multicolumn{6}{|c|}{ Affected countries } \\
\hline & Indonesia & Korea & Malaysia & Philippines & Taiwan & Thailand \\
\hline$\overline{\text { coefficient }}$ & & 0.043 & 1.782 & 0.758 & -0.386 & -0.624 \\
\hline replaced s.e. & & 0.041 & 0.117 & 0.539 & 0.183 & 0.650 \\
\hline replaced $t$ & & 1.041 & 15.229 & 1.407 & -2.106 & -0.959 \\
\hline
\end{tabular}

Note: Estimation for pre-crisis period is excluded due to the lack of d.f. 
Table 5-3 Results of Dynamic OLS: Stock Price

Panel A: Korea origin, full sample

\begin{tabular}{|c|c|c|c|c|c|c|}
\hline & \multicolumn{6}{|c|}{ Affected countries } \\
\hline & Indonesia & Korea & Malaysia & Philippines & Taiwan & Thailand \\
\hline coefficient & -0.244 & & -0.831 & -4.317 & -0.229 & 1.656 \\
\hline replaced s.e & 0.681 & & 0.121 & 0.611 & 0.117 & 0.776 \\
\hline replaced $\mathrm{t}$ & -0.359 & & -6.849 & -7.067 & -1.946 & 2.135 \\
\hline
\end{tabular}

Panel B: Korea origin, pre-crisis period

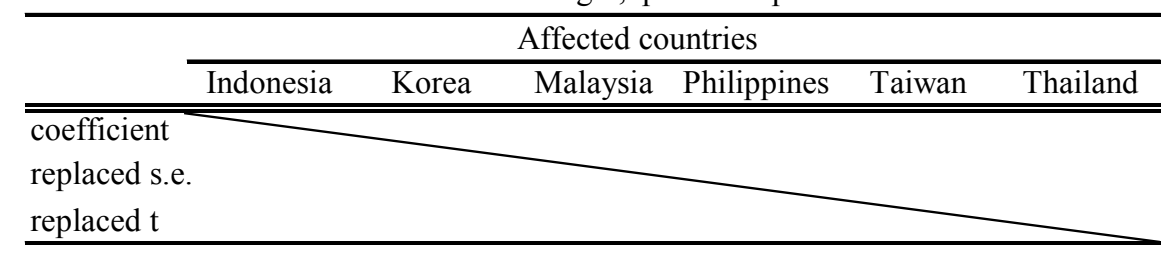

Panel C: Korea origin, post-crisis period

\begin{tabular}{|c|c|c|c|c|c|c|}
\hline & \multicolumn{6}{|c|}{ Affected countries } \\
\hline & Indonesia & Korea & Malaysia & Philippines & Taiwan & Thailand \\
\hline coefficient & -0.244 & & -0.831 & -4.317 & -0.229 & $\overline{c 1.656}$ \\
\hline replaced s.e & 0.681 & & 0.121 & 0.611 & 0.117 & 0.776 \\
\hline replaced t & -0.359 & & -6.849 & -7.067 & -1.946 & 2.135 \\
\hline
\end{tabular}

Note: Estimation for pre-crisis period is excluded due to the lack of d.f. 
Table 5-4 Results of Dynamic OLS: Stock Price

Panel A: Malaysia origin, full sample

\begin{tabular}{|c|c|c|c|c|c|c|}
\hline & \multicolumn{6}{|c|}{ Affected countries } \\
\hline & Indonesia & Korea & Malaysia & Philippines & Taiwan & Thailand \\
\hline coefficient & -1.629 & -0.422 & & -0.291 & -0.726 & 1.046 \\
\hline replaced s.e & 0.986 & 0.193 & & 0.817 & 0.136 & 0.600 \\
\hline replaced t & -1.652 & -2.180 & & -0.356 & -5.354 & 1.743 \\
\hline \multicolumn{7}{|c|}{ Panel B: Malaysia origin, pre-crisis period } \\
\hline & \multicolumn{6}{|c|}{ Affected countries } \\
\hline & Indonesia & Korea & Malaysia & Philippines & Taiwan & Thailand \\
\hline $\begin{array}{l}\text { coefficient } \\
\text { replaced s.e. } \\
\text { replaced } \mathrm{t}\end{array}$ & & & & & & \\
\hline
\end{tabular}

Panel C: Malaysia origin, post-crisis period

\begin{tabular}{|c|c|c|c|c|c|c|}
\hline & \multicolumn{6}{|c|}{ Affected countries } \\
\hline & Indonesia & Korea & Malaysia & Philippines & Taiwan & Thailand \\
\hline coefficient & -0.951 & -0.365 & & -1.779 & -1.248 & 1.264 \\
\hline replaced s.e & 0.966 & 0.227 & & 0.634 & 0.155 & 0.734 \\
\hline replaced t & -0.985 & -1.606 & & -2.804 & -8.075 & 1.722 \\
\hline
\end{tabular}

Note: Estimation for pre-crisis period is excluded due to the lack of d.f. 
Table 5-5 Results of Dynamic OLS: Stock Price

Panel A: Philippines origin, full sample

\begin{tabular}{lrrrrrr}
\hline & \multicolumn{5}{c}{ Affected countries } \\
\cline { 2 - 7 } & Indonesia & \multicolumn{1}{c}{ Korea } & Malaysia & Philippines & Taiwan & Thailand \\
\hline \hline coefficient & 0.474 & 0.660 & 1.734 & 0.545 & 0.136 \\
replaced s.e & 1.115 & 0.079 & 0.225 & 0.141 & 0.845 \\
replaced t & 0.425 & 8.344 & 7.712 & 3.853 & 0.161 \\
\hline
\end{tabular}

Panel B: Philippines origin, pre-crisis period

\begin{tabular}{lrrrrrr}
\hline & \multicolumn{5}{c}{ Affected countries } \\
\cline { 2 - 7 } & Indonesia & \multicolumn{1}{c}{ Korea } & Malaysia & Philippines & Taiwan & Thailand \\
\hline \hline coefficient & 5.298 & 2.373 & 4.152 & 0.060 & -3.358 \\
replaced s.e & 2.818 & 0.033 & 1.920 & 0.325 & 11.466 \\
replaced t & 1.880 & 72.174 & 2.163 & 0.184 & -0.293 \\
\hline
\end{tabular}

Panel C: Philippines origin, post-crisis period

\begin{tabular}{|c|c|c|c|c|c|}
\hline & \multicolumn{5}{|c|}{ Affected countries } \\
\hline & Indonesia & Korea & Malaysia Philippines & Taiwan & Thailand \\
\hline coefficient & 0.847 & 0.561 & 2.292 & 0.695 & 0.165 \\
\hline replaced s.e & 0.230 & 0.258 & 0.294 & 0.498 & 0.950 \\
\hline replaced t & 3.680 & 2.174 & 7.808 & 1.397 & 0.173 \\
\hline
\end{tabular}


Table 5-6 Results of Dynamic OLS: Stock Price

Panel A: Taiwan origin, full sample

\begin{tabular}{lrrrrrr}
\hline & \multicolumn{5}{c}{ Affected countries } \\
\cline { 2 - 6 } & Indonesia & \multicolumn{1}{c}{ Korea } & Malaysia & Philippines & Taiwan & Thailand \\
\hline \hline coefficient & 7.701 & -0.073 & 0.958 & -0.570 & 2.802 \\
replaced s.e & 1.585 & 0.024 & 0.088 & 0.435 & 1.269 \\
replaced t & 4.859 & -2.982 & 10.829 & -1.309 & 2.207 \\
\hline
\end{tabular}

Panel B: Taiwan origin, pre-crisis period

\begin{tabular}{lrrrrrr}
\hline & \multicolumn{5}{c}{ Affected countries } \\
\cline { 2 - 6 } & Indonesia & \multicolumn{1}{c}{ Korea } & Malaysia & Philippines & Taiwan & Thailand \\
\hline \hline coefficient & 12.597 & 1.273 & 2.630 & -4.544 & 8.136 \\
replaced s.e & 0.344 & 0.042 & 0.093 & 0.598 & 2.882 \\
replaced t & 36.589 & 30.346 & 28.214 & -7.601 & 2.823 \\
\hline
\end{tabular}

Panel C: Taiwan origin, post-crisis period

\begin{tabular}{|c|c|c|c|c|c|c|}
\hline & \multicolumn{6}{|c|}{ Affected countries } \\
\hline & Indonesia & Korea & Malaysia & Philippines & Taiwan & Thailand \\
\hline $\begin{array}{l}\text { coefficient } \\
\text { replaced s.e. }\end{array}$ & & & & & & \\
\hline replaced t & & & & & & \\
\hline
\end{tabular}

Note: Estimation for post-crisis period is excluded due to the lack of d.f. 
Table 5-7 Results of Dynamic OLS: Stock Price

Panel A: Thailand origin, full sample

\begin{tabular}{lrrrrrr}
\hline & \multicolumn{5}{c}{ Affected countries } \\
\cline { 2 - 7 } & Indonesia & \multicolumn{1}{c}{ Korea } & Malaysia & Philippines & Taiwan & Thailand \\
\hline \hline coefficient & -0.638 & 0.839 & 1.873 & 0.940 & 1.313 & \\
replaced s.e & 0.726 & 0.041 & 0.099 & 0.589 & 0.145 & \\
replaced t & -0.878 & 20.354 & 18.881 & 1.595 & 9.073 & \\
\hline
\end{tabular}

Panel B: Thailand origin, post-crisis period

\begin{tabular}{lrrrrrr}
\hline & \multicolumn{5}{c}{ Affected countries } \\
\cline { 2 - 7 } & Indonesia & \multicolumn{1}{c}{ Korea } & Malaysia & Philippines & Taiwan & Thailand \\
\hline \hline coefficient & -3.063 & 1.294 & 2.508 & -0.954 & 0.991 & \\
replaced s.e & 1.764 & 0.083 & 0.471 & 0.367 & 0.058 & \\
replaced t & -1.736 & 15.528 & 5.323 & -2.598 & 17.207 & \\
\hline
\end{tabular}

Panel C: Thailand origin, post-crisis period

\begin{tabular}{lrrrrrr}
\hline & \multicolumn{5}{c}{ Affected countries } \\
\cline { 2 - 7 } & Indonesia & \multicolumn{1}{c}{ Korea } & Malaysia & Philippines & \multicolumn{1}{c}{ Taiwan } & Thailand \\
\hline \hline coefficient & 0.054 & 0.567 & -0.044 & -2.513 & -1.246 & \\
replaced s.e & 2.794 & 0.126 & 0.150 & 0.878 & 0.425 & \\
replaced t & 0.019 & 4.489 & -0.294 & -2.863 & -2.929 & \\
\hline
\end{tabular}


Table 6

Export share as a percent of total exports in millions of US dollars.

1996-1999 average

\begin{tabular}{lccccc}
\hline \multirow{2}{*}{ Country } & \multicolumn{5}{c}{ Destination of Exports } \\
\cline { 2 - 6 } & Indonesia & Korea & Malaysia & Philippines & Thailand \\
\hline \hline Indonesia & & 6.442 & 2.707 & 1.437 & 1.805 \\
Korea & 3.457 & & 2.950 & 1.927 & 1.501 \\
Malaysia & 1.487 & 2.868 & & 1.443 & 3.541 \\
Philippines & 0.525 & 2.031 & 3.466 & & 2.930 \\
Thailand & 1.958 & 1.641 & 3.775 & 1.365 & \\
\hline
\end{tabular}

Notes : Authors' calculation.

Data source: IMF, Direction of Trade (2000). 
Table 7

Direct Trade Linkage Index

1996-1999 average

\begin{tabular}{lccccc}
\hline \multirow{2}{*}{ Country } & \multicolumn{5}{c}{ Countries export to and import from } \\
\cline { 2 - 6 } & Indonesia & Korea & Malaysia & Philippines & Thailand \\
\hline \hline Indonesia & & 1.090 & 1.070 & 1.668 & 0.906 \\
Korea & 0.910 & & 1.278 & 1.647 & 0.714 \\
Malaysia & 0.930 & 0.722 & & 1.095 & 1.132 \\
Philippines & 0.332 & 0.353 & 0.905 & & 1.007 \\
Thailand & 1.094 & 0.634 & 0.868 & 0.993 & \\
\hline
\end{tabular}

Notes: Authors' calculation.

Data source: IMF, Direction of Trade (2000). 
Table 8

Imcome Effect (GDP share, \%)

1996-1999 average

\begin{tabular}{lccccc}
\hline \multicolumn{1}{c}{ Origin } & \multicolumn{5}{c}{ Affected countries } \\
\cline { 2 - 6 } & Indonesia & Korea & Malaysia & Philippines & Thailand \\
\hline \hline Indonesia & & 0.06342 & 0.00014 & 0.01970 & 0.08137 \\
Korea & 0.20849 & & 0.00026 & 0.07765 & 0.06625 \\
Malaysia & 0.09224 & 0.09426 & & 0.13227 & 0.15453 \\
Philippines & 0.04789 & 0.06429 & 0.00013 & & 0.05745 \\
Thailand & 0.06157 & 0.04659 & 0.00032 & 0.10137 & \\
\hline
\end{tabular}

Notes: Authors' calculation.

Data source: IMF, Direction of Trade (2000). 
Table 9

Cheap Import effect

1996-1999 average

\begin{tabular}{lccccc}
\hline \multicolumn{1}{c}{ Origin } & \multicolumn{5}{c}{ Countries import from } \\
\cline { 2 - 6 } & Indonesia & Korea & Malaysia & Philippines & Thailand \\
\hline \hline Indonesia & & 0.08861 & 0.00018 & 0.09567 & 0.06970 \\
Korea & 0.1434 & & 0.00043 & 0.29620 & 0.14523 \\
Malaysia & 0.0597 & 0.06680 & & 0.12437 & 0.20178 \\
Philippines & 0.0066 & 0.01926 & 0.00014 & & 0.04733 \\
Thailand & 0.0683 & 0.02510 & 0.00030 & 0.10302 & \\
\hline
\end{tabular}

Notes: Authors' calculation.

Data source: IMF, Direction of Trade (2000). 
Table 10

Correlation Coefficients between Trade Link Index and Contagion coefficient

Trade Index

Export Share

DTLI

0.329

Income Effect

0.258

Cheap Import Effect

0.384 